\title{
SHiP - Search for Hidden Particles
}

\author{
Ki-Young CHOI \\ Institute for Universe and Elementary Particles \& Department of Physics, \\ Chonnam National University, Gwangju 61186, Korea

\section{Sung Hyun Kim · Kang Young LeE* • Byung Do PARK - Chun Sil Yoon \\ Department of Physics Education \& Research Institute of Natural Science, Gyeongsang National University, Jinju 52828, Korea}

\section{Yeong Gyun KIM} \\ Department of Science Education, Gwangju National University of Education, Gwangju 61204, Korea \\ Jae Woo Ko · Dong LIU · Jong Kwan $\mathrm{WOO}^{\dagger}$ \\ Department of Physics, Jeju National University, Jeju 63243, Korea \\ (Received 3 July 2016 : revised 17 July 2016 : accepted 18 July 2016)
}

The SHiP (Search for Hidden Particles) is a newly-proposed experiment (P-350) at the CERN SPS to explore hidden particles with mass from sub-GeV up to $\mathrm{O}(10) \mathrm{GeV}$. This long detector with a total length of about $150 \mathrm{~m}$ is designed to search for very-weakly-interacting long-lived particles, such as heavy neutral leptons (HNL). These particles should be produced in a proton beam dump at $400 \mathrm{GeV}$ and decay in a long, evacuated, decay volume, and the SHiP detector will perform full reconstruction and particle identification for the decay products. Moreover, the facility is suited to studying tau neutrinos by using an emulsion target. About 3500 tau neutrinos are expected for integrated $2 \times 10^{20}$ protons on target. Especially, anti-tau neutrinos are expected to be observed for the first time in this experiment. Recently, a Korean group was formed and joined the SHiP Collaboration. In this paper, the physics and the design of the SHiP experiment, including our possible contributions, are presented.

PACS numbers: 14.60.St, 14.80.Ec, 14.70.Pw, 14.60.Lm

Keywords: Hidden particle, Heavy neutral lepton, Vector portal, Scalar portal, Tau neutrino

\section{SHiP - 숨겨진 입자를 찾아서}

\author{
최기영
}

전남대학교 자연과학대학 물리학과 \& 우주소립자연구소, 광주 61186, 대한민국

\author{
김성현 · 이강영* · 박병도 · 윤천실
}

경상대학교 사범대학 물리교육과 \& 기초과학연구소, 진주 52828 , 대한민국

\section{김영균}

광주교육대학교 과학교육과, 광주 61204 , 대한민국 


\title{
고재우 · 류동 · 우종관 ${ }^{\dagger}$ \\ 제주대학교 자연과학대학 물리학과, 제주 63243 , 대한민국
}

(2016년 7월 3일 받음, 2016년 7월 17일 수정본 받음, 2016년 7월 18 일 게재 확정)

\begin{abstract}
SHiP(Search for Hidden Particles)은 유럽입자물리학연구소 CERN의 SPS 가속기를 이용해서 1 $\mathrm{GeV}$ 이하부터 수 $\mathrm{GeV}$ 까지의 질량을 가진 숨겨진 입자를 탐색하고자 제안된 실험 (P-350)이다. 총 길이 약 $150 \mathrm{~m}$ 의 SHiP은 매우 약하게 상호작용하는, 무거운 중성 렙톤 (HNL) 등의 새로운 입자들을 찾도록 설계되었다. 이 입자들은 $400 \mathrm{GeV}$ 의 양성자 빔이 표적을 때려서 만들어질 수 있고, 진공 붕괴관에서 붕괴하면 $\mathrm{SHiP}$ 검출기가 붕괴과정을 재구성하고 입자를 확인한다. 또한 $\mathrm{SHiP}$ 은 원자핵 건판을 이용해서 타우 중성미자도 연구하는데, 총 $2 \times 10^{20}$ 개의 양성자가 표적에 충돌하면 약 3500 개의 타우 중성미자가 관측될 것으로 예상된다. 특히 반-타우 중성미자를 최초로 관측할 것으로 기대한다. 최근 한국 그룹이 결성되어 $\mathrm{SHiP}$ 실험에 정식으로 합류했다. 이 논문에서는 $\mathrm{SHiP}$ 실험의 물리학과 실험 설계에 대해 설명하고 한국 그룹이 기여하고자 하는 바에 대해서 소개한다.
\end{abstract}

PACS numbers: 14.60.St, 14.80.Ec, 14.70.Pw, 14.60.Lm

Keywords: 숨겨진 입자, 무거운 중성 렙톤, 벡터 포탈, 스칼라 포탈, 타우 중성미자

\section{I. 서 론}

입자물리학의 표준모형은 약 $200 \mathrm{GeV}$ 이하의 에너지 스케일에서 일어나는 입자들의 상호작용을 거의 완전히 설 명하는 이론이다. 2012 년에 유럽입자물리학연구소 CERN 의 $\mathrm{LHC}$ 가속기를 이용한 충돌실험에서 힉스 보존이 발견 됨으로써 $[1,2]$ 표준모형에 나오는 입자는 모두 발견되었다. 반면 지금까지 어떤 실험에서도 표준모형에 나오지 않는 입자는 아무 것도 발견되지 않았으며, 또한 기본입자의 상호 작용에서 표준모형에 어긋나는 현상도 중성미자의 진동을 제외하고는 관측된 적이 없다.

어떤 입자가 자연에 존재하는데 아직 우리가 발견하지 못 했다면 그 이유는 두 가지 중 하나다. 하나는 입자의 질량이 너무 커서 아직 실험실에서 그 입자를 만들어내지 못하는 것이고, 다른 하나는 입자와 보통의 물질과의 상호작용이 너무 작아서 입자가 잘 만들어지지 않거나, 혹은 검출기 에서 좀처럼 검출하지 못하는 것이다. 질량이 큰 입자를 만들어내기 위해서는 입자를 만들어낼 수 있을 만큼 높은 에너지의 가속기가 필요하다. 지금까지 가장 높은 에너지를 내는 가속기인 LHC에서는 2016년 현재 역사상 최대 에너 지인 $13 \mathrm{TeV}$ 에서 양성자가 충돌하고 있는데, 아직 새로운 입자는 발견되지 않았다.

입자의 상호작용이 작으면 실험실에서 입자가 만들어지 거나 검출될 확률이 극히 작아서 발견하기가 어렵다. 이럴 경우에는 충돌 사건을 가능한 한 많게 해서 입자가 만들어 질 가능성을 높이는 일이 필요하다. 이런 실험을 ‘더 많은

*E-mail: kylee.phys@gnu.ac.kr

${ }^{\dagger} \mathrm{E}$-mail: w00jk@jejunu.ac.kr
입자를 추구하는 (intensity frontier) 실험' 이라고 부른다. $\mathrm{SHiP}$ 실험은 $\mathrm{CERN}$ 의 SPS 가속기를 이용해서 아직까지 발견되지 않은 '숨겨진 입자' (hidden particle)를 만들어 내고 이를 특별히 설계된 검출 장치를 통해 표준모형의 입 자들과 분리해서 탐색하고자하는 실험이다 [3-5]. 그래서 실험의 이름도 "Search for Hidden Particles" 의 약자를 따 서 정해졌다. 숨겨진 입자란 표준모형의 입자와 상호작용이 매우 작아서 보통의 실험에서는 나타나지 않는 입자로서, 예를 들어 새로운 중성미자, 액시온, 암흑광자 등과 같이 표준모형의 게이지 상호작용을 하지 않는 새로운 입자들이 여기에 속한다. $\mathrm{SHiP}$ 실험에서 발견하려는 입자는 질량이 $1 \mathrm{GeV}$ 정도이고, 만들어지고 나서 수 $\mathrm{m}$ 에서 $50 \mathrm{~m}$ 이상을 날아갈 만큼 수명이 긴 입자다. 이런 성질을 가지는 입자는 $\mathrm{LHC}$ 를 비롯한 지금까지의 가속기 실험에서는 검출될 수 없었다. 이와 같은 입자들의 발견은 암흑물질을 비롯해서, 중성미자 질량의 기원 및 진동, 우주의 물질-반물질 비대칭 성 등과 같이 입자물리학 및 우주론에서 매우 중요하면서도 표준모형에서 설명할 수 없는 문제들을 해결해줄 수 있다 [4].

중성미자는 상호작용을 아주 약하게 한다는 면에서 우리 가 발견하고자 하는 숨겨진 입자와 성질이 매우 유사하다. 그래서 $\mathrm{SHiP}$ 에서는 중성미자를 검출하는 실험도 함께 진행 한다. 중성미자 검출기는 원자핵 건판 (nuclear emulsion) 검출기다. $\mathrm{SHiP}$ 실험에서는 특히 타우 중성미자를 약 3500 여개를 검출하여 타우 중성미자들의 밝혀지지 않은 성질들 을 규명할 예정이며, 반-타우중성미자를 최초로 발견할 수 있을 것으로 예상하고 있다 [3-5].

이러한 '더 많은 입자를 추구하는 실험' 으로 숨겨진 입 자들을 찾는 일은 Fig. 1 에서 보듯이 $\mathrm{LHC}$ 와 같은 '더 높은 


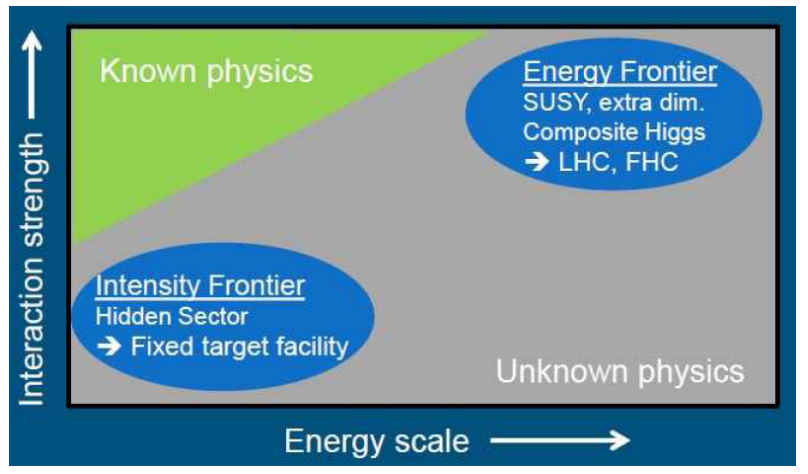

Fig. 1. (Color online) Intensity frontier experiment and energy frontier experiment [4].

에너지를 추구하는 (energy frontier) 실험' 과 상호보완적 으로 수행되는 실험이라 할 수 있다. 따라서 이러한 실험은 $\mathrm{LHC}$ 가 한참 더 높은 에너지 영역을 탐구하고 있는 지금, 매우 시의적절하고 중요한 실험이다.

본 논문의 2 장에서는 $\mathrm{SHiP}$ 실험을 통해 검출하려는 숨 겨진 입자들의 이론적 배경이 되는 모형을 개관한다. 3 장에서는 이들 입자들을 실험에서 어떻게 검출할 것인지를 논의하고, 4 장에서 숨겨진 입자 검출기와 중성미자 검출기 등 $\mathrm{SHiP}$ 실험장치에 대해 설명한다. 5 장에서는 실험에 참 여하는 한국 그룹을 소개하고, 한국 그룹이 기여할 부분에 대해 설명한다. 마지막으로 6 장에서 $\mathrm{SHiP}$ 실험의 중장기 계획과 앞으로의 전망을 논의한다.

\section{II. 이론적 배경}

\section{1. 벡터 포탈}

1) 새로운 $\mathrm{U}(1)$ 게이지 입자와 벡터 포탈

입자물리의 표준모형에서는 $S U(3) \times S U(2) \times U(1)$ 게 이지 군으로 강한 핵력, 약한 핵력, 전자기력을 기술하면서 각각의 게이지 군에 해당하는 게이지 입자로 힘을 매개한다. 만약 표준모형을 넘어서는 이론에서 새로운 게이지 상호 작용이 존재한다면 그에 해당하는 새로운 형태의 게이지 입자가 존재할 것이다.

새로운 $U(1)$ 게이지 군이 존재할 때, 이를 표준모형의 $U(1)$ 과 구별하여 $U(1)^{\prime}$ 이라고 하고 $U(1)^{\prime}$ 의 게이지 입자 를 $B^{\prime}$ 이라고 하자. 이 경우 표준모형의 게이지 입자인 $B$ 와 $B^{\prime}$ 의 운동항은 일반적으로 섞여질 수 있다. 운동항의 라그랑지안은 [6]

$$
L=-\frac{1}{4} \widehat{B_{\mu \nu}} \widehat{B^{\mu \nu}}-\frac{1}{4} \widehat{B_{\mu \nu}^{\prime}} \widehat{B^{\prime \mu \nu}}+\frac{\epsilon}{2 \cos \theta_{W}} \widehat{B_{\mu \nu}} \widehat{B^{\prime \mu \nu}}
$$

로 주어지며, 여기서 $\widehat{B^{\mu \nu}}$ 와 $\widehat{B^{\prime \mu \nu}}$ 는 각각 $U(1)$ 과 $U(1)^{\prime}$ 군의 게이지 장 세기 텐서에 해당하고, $\theta_{W}$ 는 와인버그 섞 임각이다. 세 번째 항이 두 입자의 섞임을 나타내며 섞임의 정도는 $\epsilon$ 로 표현된다.

표준 모형의 알려진 구역 (visible sector) 과 상호작용을 하지 않는 숨겨진 구역 (hidden sector) 이 자연에 존재하고, 일반적으로 $U(1)^{\prime}$ 게이지 입자가 숨겨진 구역의 입자들과 상호작용을 한다면, 숨겨진 구역의 입자들도 $U(1)^{\prime}$ 게이지 입자를 통해서 알려진 구역과 상호작용을 할 수 있다. 예를 들어 숨겨진 구역에 대한 라그랑지안

$$
L_{\chi}=\bar{\chi}\left(i \gamma^{\mu} D_{\mu}-m_{\chi}\right) \chi
$$

을 생각하자. 여기서 공변미분은 $D_{\mu}=\partial_{\mu}+i g_{d} B_{\mu}^{\prime}$ 다. 이 식에서 숨겨진 구역의 페르미온 입자 $\chi$ 는 $B^{\prime}$ 게이지 입자와 상호작용을 하고, $B^{\prime}$ 은 위의 운동항 섞임을 통해 표준모형 의 게이지 입자 $B$ 와 다음과 같이 연결된다.

$$
L_{Z^{\prime}}=-e \epsilon J_{E M}^{\mu} A_{\mu}^{\prime}+g_{d}^{\prime} \bar{\chi} \gamma^{\mu} \chi A_{\mu}^{\prime} .
$$

$J_{E M}^{\mu}$ 는 전자기 전류이고 $e$ 는 전자기 결합상수, 그리고 $g_{d}^{\prime}=$ $g_{d} / \sqrt{1-\epsilon^{2} \cos ^{2} \theta_{W}}, A_{\mu}^{\prime}=B_{\mu}^{\prime} \sqrt{1-\epsilon^{2} \cos ^{2} \theta_{W}}$ 이다. 한편 $B$ 는 표준모형의 게이지 입자이므로 쿼크와 렙톤 등 표준 모형의 입자들과 상호작용을 한다. 이런 일련의 과정을 통하여 숨겨진 구역과 알려진 구역이 서로 소통하게 되며, 이때 $B^{\prime}$ 입자는 두 구역을 연결시키는 문 (portal) 의 역할을 한다. 이런 의미에서 이러한 모형을 벡터 포탈 모형이라고 한다. 여기서 $A^{\prime}$ 을 암흑광자라고 부르는데, 일반적으로 암 흑광자는 숨겨진 영역을 통하여 질량 $m_{A^{\prime}}$ 을 가질 수 있다.

암흑광자 $A^{\prime}$ 의 질량이 $\mathrm{GeV}$ 정도이고 상호작용이 약하 면, $\mathrm{LHC}$ 에서는 검출하기가 쉽지 않지만 $\mathrm{SHiP}$ 과 같이 더 많은 입자를 추구하는 실험에서는 새로운 현상을 관찰할 가능성이 있다. 그러므로 $\mathrm{SHiP}$ 실험은 암흑광자가 나오는 벡터 포탈 모형에 주목을 하고 있다.

\section{2) 물리적 동기}

$\mathrm{GeV}$ 정도의 가벼운 질량을 가진 암흑광자를 통해 잘 설명될 수 있는 물리적 현상들은 지상의 실험과 천체물리 관측, 그리고 우주론적 현상에 두루 존재한다. 다음에 몇 가지 물리적 동기들을 정리하였다.

뮤온 $g-2$ : 실험에서 관측된 뮤온의 자기 쌍극자모멘트는 표준모형의 이론에서 계산한 값보다 3- $\sigma$ 정도의 큰 차이를 보이고 있다 [7]. 이 차이를 설명하려면 $\Delta a_{\mu} \sim 3 \times 10^{-9}$ 정도에 해당하는 새로운 양이 이론적으로 추가되어야 한다. 
이를 설명하는 한 가지 방법이 $100 \mathrm{MeV}$ 정도의 질량을 가지 고 있으며 섞임의 정도가 $\epsilon \sim 10^{-3}$ 인 암흑광자가 존재하는 것이다. 초기에 제기된 가장 간단한 이론적 모형은 현재까 지의 실험에 의하여 배제되었지만, 암흑물질과 암흑광자가 결합하는 확장된 모형에서는 여전히 그 가능성이 남아있다.

천체물리 관측 : 암흑물질은 우리 은하 주변에 모여 있으 며, 엑스선, 감마선 등의 여분의 우주선을 발생할 수 있다. 특히 최근 우리 은하 중심에서 $511 \mathrm{keV}$ 의 광자가 이론적 예 측보다 많이 관측되었으므로 이에 대한 새로운 설명방법이 필요하게 되었다 [8]. 만약 $100 \mathrm{MeV}$ 정도의 질량을 가지는 암흑광자를 매개로 $\mathrm{MeV}$ 질량의 암흑물질이 쌍소멸 한다면 현재 관측된 우주선을 설명할 수 있는 여분의 광자가 나타날 수 있다.

스스로 상호작용하는 암흑물질 (self-interacting dark matter) : 차가운 암흑물질 모형은 천체물리 관측과 우주 론적 현상에서 나타나는 큰 규모에서의 중력을 통한 관측과 중력 외의 방법으로 얻은 관측 결과 사이의 불일치를 아주 잘 설명하고 있다. 하지만 작은 규모의 구조에서는 이론과 관측이 약간의 차이를 보이고 있다. 예를 들면, 왜소 은하의 중심에서 암흑물질의 밀도가 너무 크게 나온다거나 $[9,10]$, 우리 은하 주변의 위성은하의 관측된 개수가 시뮬레이션보 다 적게 나오는 것 등이다 $[11,12]$. 암흑물질의 질량이 수 $\mathrm{MeV}$ 에서 수 $\mathrm{GeV}$ 정도이고, 암흑광자가 매개해서 암흑물 질들 사이에 상호작용이 있으면 $\left(g_{d}^{\prime} \sim 0.01\right)$ 이러한 차이를 설명할 수 있다.

\section{3) $\mathrm{SHiP}$ 에서 암흑광자의 붕괴율}

고정 표적 실험에서 암흑광자를 탐색하는 일은 고에너지 빔이 표적에 충돌하여서 암흑광자가 만들어지고 여기서 붕괴되어 나오는 입자들을 검출하는 것이다. 암흑광자의 주요한 붕괴 방법은 크게 표준 모형의 렙톤과 하드론, 그리 고 숨겨진 입자들로 붕괴하는 세 가지로 나눌 수 있다. 즉

$\Gamma_{A^{\prime}}=\sum_{l} \Gamma_{A^{\prime} \rightarrow l^{+} l^{-}}+\sum_{\text {hadron }} \Gamma_{A^{\prime} \rightarrow \text { hadron }}+\sum_{\chi} \Gamma_{A^{\prime} \rightarrow \bar{\chi} \chi}$

이다. 여기서 렙톤과 $\chi$ 로의 붕괴율은

$$
\begin{aligned}
\Gamma_{A^{\prime} \rightarrow l^{+} l^{-}} & =\frac{1}{3} \epsilon^{2} \alpha\left(1+\frac{2 m_{l}^{2}}{m_{A^{\prime}}^{2}}\right) \sqrt{1-\frac{4 m_{l}^{2}}{m_{A^{\prime}}^{2}}} \\
\Gamma_{A^{\prime} \rightarrow \bar{\chi} \chi} & =\frac{1}{3} \alpha_{D}\left(1+\frac{2 m_{\chi}^{2}}{m_{A^{\prime}}^{2}}\right) \sqrt{1-\frac{4 m_{\chi}^{2}}{m_{A^{\prime}}^{2}}}
\end{aligned}
$$

이므로 보이는 과정과 보이지 않는 과정의 붕괴율 비는 일반적으로 $\sim \alpha \epsilon^{2} / \alpha_{D}$ 정도에 해당한다. 여기서 $\alpha$ 는 미 세구조상수이며 $\alpha_{D}=g_{D}^{2} / 4 \pi$ 이다. 대부분의 암흑광자가 알려진 구역의 입자로 붕괴한다면, 붕괴 거리는 $m_{Z^{\prime}}$ 가 200 $\mathrm{MeV}$ 일 때,

$$
c \tau_{A^{\prime}} \gamma \sim 40 m\left(\frac{10^{-6}}{\epsilon}\right)^{2} \times \frac{\gamma}{100}
$$

정도이다. 즉 $\mathrm{SHiP}$ 에서 만들어진 입자의 에너지가 $\mathrm{GeV}$ 정도이고 검출기까지의 거리가 $100 \mathrm{~m}$ 정도라면 섞임이 $10^{-6}$ 정도일 때 가벼운 암흑광자를 가장 잘 검출할 수 있다.

반대로 $\alpha_{D} \gg \alpha \epsilon^{2}$ 인 경우에는 암흑광자의 대부분이 숨겨진 구역의 입자로 붕괴한다. 이 경우 만들어지는 $\chi$ 는 대부분 관측되지 않으므로 검출이 어려워진다. 그러나 확률은 낮지만 $\chi$ 가 검출기의 전자나 핵자와 산란할 수도 있으므로 그러한 가능성에 대해서도 계속 연구되고 있다.

\section{4) $\mathrm{SHiP}$ 에서 암흑광자의 생성}

$\mathrm{SHiP}$ 에서 암 흑광자 는 메 존붕 괴, 제 동복사 (bremsstrahlung), 그리고 직접적인 $\mathrm{QCD}$ 섭동과정 (perturbative QCD production) 이라는 세 가지 방법에 의해서 생성된다.

메존붕괴 : 양성자가 표적에 충돌하여 $\pi, K, D$ 와 같은 메존들이 생성된다. $\pi^{0}$ 는 주로 두 개의 광자로 붕괴를 하 는데 그 중 하나가 암흑광자와의 섞임을 통하여 $\pi \rightarrow \gamma A^{\prime}$ 으로 붕괴할 수 있다. 이 때 생성율은 $\epsilon^{2}$ 에 비례한다. 다른 메존들도 붕괴할 때 암흑광자를 생성할 수 있다.

제동복사 : 양성자가 표적에 있는 핵자와 충돌할 때의 제동 복사에 의하여 광자가 생성되는데 이 때 섞임을 통하여 암흑광자가 생성될 수 있다

$\mathrm{QCD}$ 섭동과정 : 암흑광자의 질량이 큰 경우 쿼크들에 의한 $\mathrm{QCD}$ 과정에서 $q+\bar{q} \rightarrow A^{\prime}, g+g \rightarrow g+A^{\prime}$ 과정을 통하여 암흑광자가 직접 생성될 수 있다.

\section{5) SHiP에서의 연구}

Fig. 2는 알려진 구역으로 붕괴하는 암흑광자 연구에 대 한 현재까지의 실험 결과와 $\mathrm{SHiP}$ 에서 탐색 가능한 영역을 나타낸 것이다. 회색 영역이 현재까지 실험에서 탐색한 영역이다. 이 영역은 두 부분으로 나눌 수 있는데, 암흑광 자가 발생 즉시 붕괴하는 경우와 $\left(\epsilon^{2}>10^{-6}\right)$, 시간을 두고 


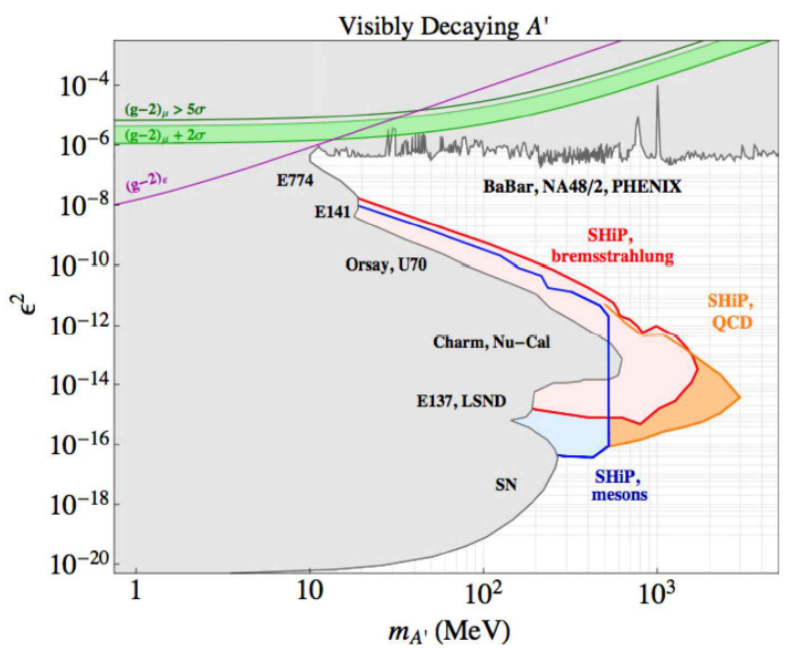

Fig. 2. (Color online) Summary of constraints on the dark photon model [4].

붕괴하여 표적으로부터 멀리 날아간 뒤 붕괴하는 경우이다 $\left(\epsilon^{2}<10^{-6}\right)$.

후자의 경우에서 $\epsilon^{2} \sim 10^{-14}$ 인 경우에는 암흑광자의 질 량이 $600 \mathrm{MeV}$ 정도까지 이르는 영역까지 탐색되었다. 그 위쪽 영역에서는 암흑광자가 검출기에 이르기 전에 붕괴해 버리기 때문에, 그리고 그 아래 영역에서는 섞임이 너무 적어 생성과 검출이 어렵기 때문에 탐색할 수 있는 영역이 횔씬 줄어든다.

$\mathrm{SHiP}$ 실험이 이전의 실험들에 비해 새로운 점은, 표적에 충돌하는 양성자의 수를 크게 증가시키고 검출기를 표적에 더 가깝게 함으로써 이전 실험에서 도달하지 못하였던 영 역을 탐색한다는 것이다. $\mathrm{SHiP}$ 에서 새로이 탐색할 수 있는 탐색영역을 암흑광자의 생성방법에 따라 푸른색, 빨간색, 주황색으로 나타내었다. 푸른색은 메존 붕괴, 빨간색은 제 동 복사, 그리고 주황색은 $\mathrm{QCD}$ 과정에 의한 것이다. 그림 에서 보듯이 $\epsilon^{2} \sim 10^{-14}$ 일 때는 암흑광자의 질량이 $2 \mathrm{GeV}$ 에 이를 때까지도 탐색할 수 있을 것으로 기대하고 있다.

대부분의 암흑광자가 숨겨진 구역으로 붕괴하게 되면 검 출하기는 더 어려워진다. Fig. 3은 암흑광자가 암흑물질로 붕괴하고 그 암흑물질을 검출하는 가능성을 연구한 것이다. 즉,

$$
p p \rightarrow \pi^{0}+X, \pi^{0} \rightarrow \gamma A^{\prime}, \quad A^{\prime} \rightarrow \chi \bar{\chi}
$$

과정을 생각했다. 양성자 충돌에 의하여 생성된 $\pi$ 가 붕 괴해서 암흑광자를 만들고, 곧 이어 암흑광자도 붕괴해서 암흑물질 $\chi$ 를 만들어낸다. 이렇게 생성된 $\chi$ 는 검출기의 전자나 핵자와 산란을 하게 된다. 회색 영역이 현재까지의 실험에 의하여 배제된 영역이다. $\epsilon^{2}<10^{-6}$ 인 영역에서는 현재 LSND (Liquid Scintillator Neutrino Detector) 가 가

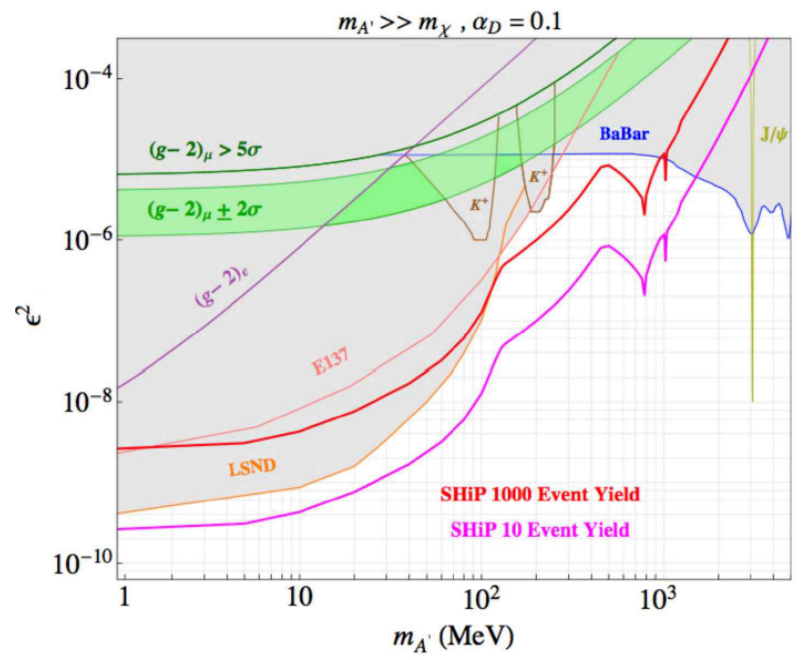

Fig. 3. (Color online) Summary of the constraints on the scattering of the light dark matter production in epcollisions with fixed targets [4].

장 자세하게 탐색했다 [13]. SHiP에서 만들어진 암흑물질 이 전자와 산란해서 10 개 ( 1000 개) 의 사건을 만들어내는 경우가 분홍색 (빨간색) 선으로 표시되어 있다.

\section{2. 스칼라 포탈}

1) 힉스 포탈

2012년 CERN LHC 실험을 통해 힉스 입자가 발견된 이 후, 힉스 포탈을 통해서 숨겨진 구역을 탐색하는 연구는 매 우 중요한 주제가 되었다. 힉스 장 $H$ 의 질량 항인 $H^{\dagger} H$ 는 표준모형의 게이지 변환과 로렌츠 변환에 대해 불변이고 질 량 차원 (mass dimension) 이 2 인 항이기 때문에, 표준모형 게이지 군에 대해 단일항 (singlet) 인 스칼라 장 $S$ 와 재규격 가능한 상호작용으로 연결될 수 있다. 이 상호작용을 통해 표준모형 단일항인 장들로 구성된 이른바 숨겨진 구역은 표준모형 장들로 이루어진 알려진 구역과 상호작용을 가질 수 있게 된다. 이런 의미에서 이러한 모형을 스칼라 포탈 모형이라 부른다 [14].

표준모형 단일항인 실수 스칼라 $S$ 를 포함하는 가장 일 반적인 재규격 가능한 라그랑지안은 다음과 같이 주어진다 [15-17].

$$
\begin{aligned}
L= & L_{S M}+\frac{1}{2} \partial_{\mu} S \partial^{\mu} S+\left(\alpha_{1} S+\alpha_{2} S^{2}\right) H^{\dagger} H \\
& +\lambda_{2} S^{2}+\lambda_{3} S^{3}+\lambda_{4} S^{4} .
\end{aligned}
$$

여기서 $L_{S M}$ 은 표준모형 라그랑지안을 나타낸다. 힉스 포탈 항 $\left(\alpha_{1} S+\alpha_{2} S^{2}\right) H^{\dagger} H$ 은 표준모형 힉스와 단일항 스칼라 

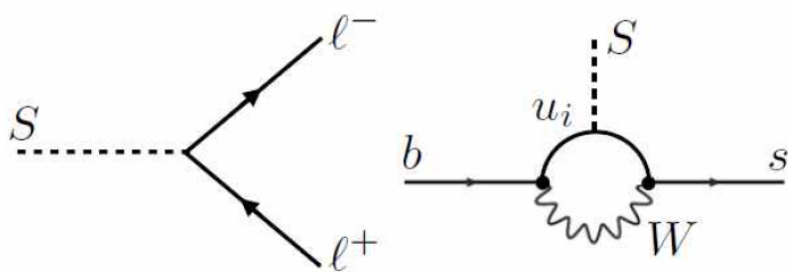

Fig. 4. Decay and production of the singlet scalar $S$.

사이에 섞임을 주며, 그들 사이의 자체 상호작용을 만든다. 스칼라 $S$ 의 질량이 전기-약작용의 에너지 스케일보다 현저 히 낮다고 가정하면, 유효 라그랑지안은 다음과 같다.

$$
L=L_{S M}-\frac{g_{*} m_{f}}{v} S \bar{f} f+L_{\text {self }} .
$$

여기서 $v \sim 246 \mathrm{GeV}$ 는 전기-약작용의 진공기대값이고 $f$ 는 질량이 $m_{f}$ 인 표준모형의 페르미온이며, 마지막 항은 $S$ 의 자체 상호작용을 나타낸다. 스칼라 $S$ 와 표준모형 페 르미온들의 상호작용의 세기는 표준모형 힉스와 페르미온 사이의 유카와 상호작용 세기에 비해 $g_{*}$ 배 만큼 작아진다. 섞임각 $\theta$ 가 작고 스칼라 $S$ 의 질량이 힉스 질량보다 훨씬 작을 때 $\left(m_{S} \ll m_{h}\right)$, 섞임각은 다음과 같이 주어진다.

$$
g_{*}=\sin \theta \simeq \theta \approx \frac{\alpha_{1} v}{m_{h}^{2}} .
$$

낮은 에너지 영역에서의 현상론은 표준모형 매개변수에 새롭게 추가된 두 개의 매개변수, 즉 힉스-스칼라 섞임 매 개변수 $g_{*}$ 와 $S$ 의 질량 $m_{S}$ 에 의해 결정된다.

\section{2) SHiP에서 스칼라 입자의 탐색}

$\mathrm{SHiP}$ 실험에서 유카와 상호작용을 하는 가벼운 스칼라 입자들은 $B$ 메존이나 케이온 등의 붕괴로부터 주로 생성될 것이다. $\mathrm{SHiP}$ 은 5 년간 가동될 계획인데, 이 기간 동안에 $2 \times 10^{20}$ 개의 양성자가 텅스텐-몰리브덴 표적에 충돌할 것이며 이로부터 $8 \times 10^{17}$ 개의 케이온과 $7 \times 10^{13}$ 개의 $B$ 메존 $\left(N_{B}=7 \times 10^{13}\right)$ 이 생성될 것으로 예상된다. $\mathrm{SHiP}$ 실험은 케이온이 붕괴되기 전에 흡수되도록 설계되어 있기 때문에, 케이온이 $B$ 메존 보다 더 많이 생성되지만, 케이 온의 붕괴로부터 $\mathrm{SHiP}$ 검출기 방향으로 생성되는 스칼라 입자의 수는 제한적일 것이다 [4].

$B$ 메존의 경우, 스칼라 입자 $S$ 는 $B \rightarrow K S$ 와 같은 $B$ 메존의 희소 붕괴로부터 생성된다. 이렇게 생성된 스칼라 입자는 힉스-스칼라 섞임을 통해 최종적으로 표준모형 페 르미온으로 붕괴된다. Fig. 4 는 스칼라 입자가 표준모형 렙톤으로 붕괴되는 과정과, $B \rightarrow K S$ 붕괴를 나타내는
파인만 도형이다. 여기서 $b$ 와 $s$ 는 각각 $b$ 쿼크와 $s$ 쿼크를 나타낸다.

이 파인만 도형에 대한 유효 라그랑지안은 아래와 같으며 이로부터 $B \rightarrow K S$ 붕괴의 갈래비를 쉽게 계산할 수 있다.

$$
L \supset \frac{3 \sqrt{2} G_{F} m_{t}^{2} V_{t s}^{*} V_{t b}}{16 \pi^{2}} \frac{m_{b}}{v} g_{*} S \overline{s_{L}} b_{R}+\text { h.c. }
$$

$B$ 메존의 붕괴로부터 생성된 스칼라 입자의 개수는 $N_{S}=$ $N_{B} \times \operatorname{Br}(B \rightarrow K S)$ 로 주어진다.

스칼라 $S$ 는 최종적으로 표준모형 입자들로 붕괴하는데, 스칼라 입자의 질량이 전자 질량의 2 배보다 크고 가장 가벼 운 하드론 질량의 2 배보다 작을 때는 스칼라 입자가 주로 전자나 뮤온으로 붕괴할 것이다.

$$
S \rightarrow \gamma \gamma, e^{+} e^{-}, \mu^{+} \mu^{-}, \pi \pi, K K .
$$

이 때의 붕괴폭은 다음과 같이 주어진다.

$$
\Gamma(S \rightarrow l \bar{l})=\frac{g_{*}^{2} m_{l}^{2} m_{S}}{8 \pi v^{2}}\left(1-\frac{4 m_{l}^{2}}{m_{S}^{2}}\right)^{3 / 2} .
$$

스칼라의 상호작용 결합상수는 페르미온의 질량에 비례하기 때문에, 스칼라 입자가 뮤온 질량의 2 배보다 무거운가 가벼 운가에 따라서 입자의 수명이 다음과 같이 크게 달라진다.

$c \tau_{S} \simeq 50 m \times \begin{cases}\left(\frac{0.02}{g_{*}}\right)^{2}\left(\frac{50 \mathrm{MeV}}{m_{S}}\right) & \text { for } m_{S}<2 m_{\mu} \\ \left(\frac{5 \times 10^{-5}}{g_{*}}\right)^{2}\left(\frac{250 \mathrm{MeV}}{m_{S}}\right) & \text { for } m_{S}>2 m_{\mu}\end{cases}$

검출기 영역에서 붕괴되는 개수는 생성된 스칼라의 개수 $N_{S}$ 에 검출기 내부에서 스칼라 입자가 붕괴할 확률을 곱 해서 계산할 수 있다. 검출기가 표적으로부터 거리 $l(70$ $\mathrm{m})$ 만큼 떨어져 있고 검출기의 길이가 $\Delta l(55 \mathrm{~m})$ 이라면 검출기 영역에서 붕괴되는 스칼라 입자의 개수는 다음과 같이 주어진다.

$$
N_{\text {det }} \sim N_{S}\left[\exp \left(-\frac{l}{\gamma \beta c \tau_{S}}\right)-\exp \left(-\frac{l+\Delta l}{\gamma \beta c \tau_{S}}\right)\right]
$$

여기서 $\tau_{S}$ 는 스칼라 입자의 수명이고 $\gamma=E_{S} / m_{S}$ 는 상대 론적 감마 인자이다.

$E_{S} \sim 25 \mathrm{GeV}$ 로 택하고, $\mathrm{SHiP}$ 실험에서는 배경사건이 전혀 없다고 가정하면 $N_{d e t}>3$ 의 예측치를 주는 모든 매 개변수 영역을 배제시킬 수 있다. Fig. 5 는 가벼운 스칼라 입자에 대한 현재까지의 실험으로 탐색되어 배제된 영역과 함께 $\mathrm{SHiP}$ 실험에 의해 검증될 영역을 보여준다. 스칼라 입자들이 너무 빨리 혹은 너무 느리게 붕괴하면 관측이 어 렵기 때문에 검증될 영역의 모양이 그림과 같이 결정된다.

스칼라 입자가 숨겨진 구역에 속하는 암흑물질과 표준모 형 핵자 사이의 상호작용을 매개하도록 이론을 확장할 수도 


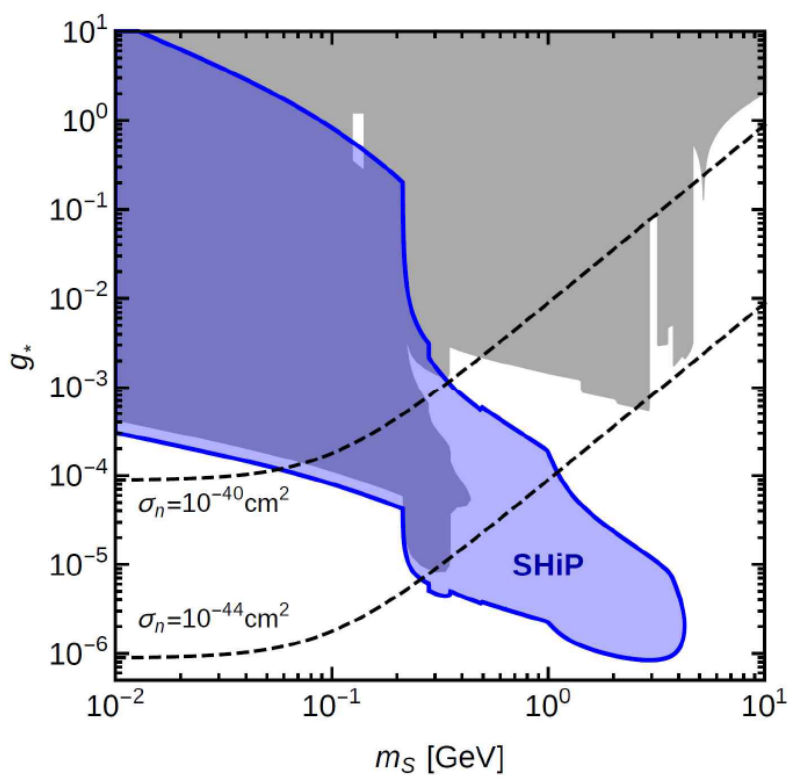

Fig. 5. (Color online) Projected sensitivity of SHiP for a scalar $S$ with Yukawa-like couplings to all SM fermions, in comparison to the existing bounds [4].

있다. 이렇게 확장된 형태 중에서 최소 모형의 라그랑지안은 다음과 같이 주어진다.

$$
L=L_{S M}-\frac{g_{*} m_{f}}{v} S \bar{f} f-\frac{1}{2} \kappa \bar{\chi} \chi+\ldots
$$

여기서 $\chi$ 는 마요라나 페르미온인 암흑물질 입자를 나타낸 다. 이런 모형에서는 $\mathrm{SHiP}$ 실험에서 기대되는 실험 민감도 와 직접적 암흑물질 관측실험의 민감도를 비교할 수 있다. 암흑물질과 스칼라 사이의 상호작용 매개변수를 $\kappa=0.1$ 이라고 가정하면, 현재 LUX 실험의 핵자-암흑물질 탄성충 돌 산란단면적에 대한 실험의 상한값은 암흑물질의 질량 $m_{\chi}=5(10) \mathrm{GeV}$ 에 대해 $\sigma_{n}=10^{-40}\left(10^{-44}\right) \mathrm{cm}^{2}$ 이다 [18, 19]. 이에 대응되는 윤곽선이 Fig. 5 에 점선으로 표시되어 있다. Fig. 5 에서 확인할 수 있는 것처럼, $\mathrm{SHiP}$ 실험은 현재의 가속기 실험이나 암흑물질 실험으로는 접근할 수 없는 스칼라 입자의 질량과 결합상수 영역을 탐색할 것으로 기대된다.

\section{3. 중성미자 포탈}

중성미자 포탈 모형이란 표준모형의 게이지 대칭성에 대해서 상호작용을 하지 않는 새로운 페르미온이 존재해서, 다음과 같이 렙톤 이중항과 힉스 이중항의 곱으로 이루어진 게이지 불변인 연산자 $\left(\overline{L_{\alpha}} \cdot \tilde{\Phi}\right)$ 와 유카와 결합 형태의 상호 작용을 하는 모형이다.

$$
L_{\text {중성미자포탈 }}=F_{\alpha I}\left(\overline{L_{\alpha}} \cdot \tilde{\Phi}\right) N_{I}+h . c .
$$

여기서 $F_{\alpha I}$ 는 차원이 없는 유카와 결합 상수이며 일반적으 로 복소수다. $\alpha$ 는 렙톤의 종류 $\{e, \mu, \tau\}$ 를 나타내는 첨자이 며 $I$ 는 새로운 페르미온의 종류를 나타내는 첨자다. 렙톤 이중항이 좌회전성 페르미온이므로 새로운 페르미온 중에 서 우회전 성분만이 위와 같은 형태로 표준모형의 입자들과 상호작용을 하게 된다.

힉스 이중항이 전자기약작용의 대칭성을 깨기 위해 진공 기대값을 가지게 되면 위의 항은 새로운 페르미온과 중성미 자의 섞임 항이 된다. 그러면 새로운 페르미온은 만약 질량 이 허용되는 값이라면 중성미자가 생성될 때 같은 방식으로 생성될 수 있다. 그렇기 때문에 이 새로운 페르미온을 종종 '무거운 중성미자' , 혹은 ‘죽은 중성미자 (sterile neutrino)' 라고 부르고, 좀 더 중립적으로 ‘무거운 중성 렙톤 (Heavy Neutral Lepton, HNL)' 이라고도 한다. 여기서는 앞으로 $\mathrm{HNL}$ 이라는 이름으로 부르도록 하겠다. 이렇게 중성미 자를 통해서 숨겨진 구역의 입자들이 표준모형의 알려진 입자들과 상호작용을 하므로 이러한 모형을 중성미자 포탈 모형이라고 부른다.

$\mathrm{HNL}$ 은 일반적으로 위의 유카와 항과는 무관하게 질량을 가질 수 있다. 이 질량에는 아무런 제약도 없다. 디랙 질량일 수도 있고 마요라나 질량일 수도 있으며, 질량 값도 수 $\mathrm{eV}$ 에서 대통일 이론의 스케일까지 모두 가능하다. 만약 HNL 이 마요라나 질량을 가진다면 위의 중성미자 포탈 항과 함께 중성미자-HNL 질량 행렬을 다음과 같이 쓸 수 있는데,

$$
M_{\nu N}=\left(\begin{array}{cc}
0 & m_{D} \\
m_{D}^{T} & M_{I}
\end{array}\right) .
$$

여기서 디랙 질량인 $m_{D}$ 는 위의 중성미자 포탈 항에서 온 것이다. 이 질량행렬을 대각화시키면 이제 물리적인 질량을 얻을 수 있다. 중성미자의 질량은 5 차원의 소위 와인버그 연산자 형태인

$$
\left(M_{\nu}\right)_{\alpha \beta}=-\sum_{I}\left(m_{D}\right)_{\alpha I} \frac{1}{M_{I}}\left(m_{D}\right)_{\beta I},
$$

로 주어지는데, 특히 $m_{D} \ll M_{I}$ 이면 자연스럽게 매우 작 은 값을 가지게 된다. 중성미자의 질량이 작은 이유를 설 명하는 가장 우아한 방법인 이 과정을 시소 과정 (see-saw mechanism) 이라 부른다 [20-23]. 이때 HNL 과 중성미자 는 디랙 질량과 마요라나 질량의 비 정도의 크기로 섞이게 된다.

만약 $\mathrm{HNL}$ 이 우회전성 페르미온이며 세 개만 존재한다 면, 이는 정확히 표준모형에서 중성미자의 우회전 성분으로 생각할 수 있다. 이런 모형은 Fig. 6 에서 보듯이 표준모형에 결여되어있는 중성미자 부분만을 채워주기 때문에 표준모형 을 최소한으로 확장한 모형이라고 할 수 있다. 이러한 모델 


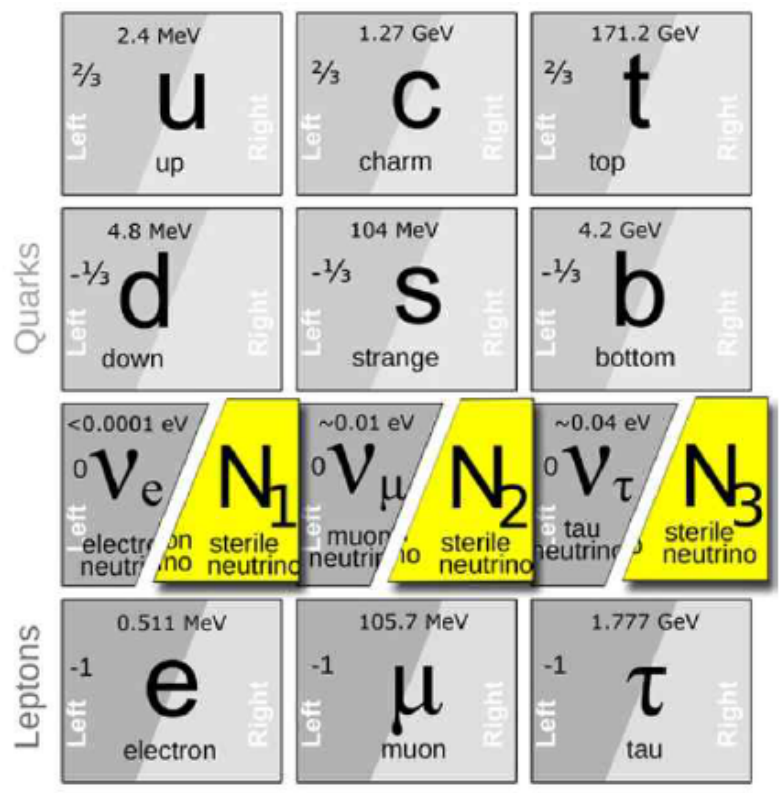

Fig. 6. (Color online) The fermions of the SM added by three "sterile neutrinos" [4].

을 중성미자-최소 표준모형 ( $\nu$ Minimal Standard Model, $\nu \mathrm{MSM}$ ) 이라고 부른다. 그런데 놀라운 것은 이렇게 간단한 확장 모형만으로도 질량과 결합상수가 적절한 값을 가지기 만 하면 암흑물질을 비록해서 표준모형에서 아직 해결하지 못한 많은 문제들을 해결할 수 있다는 것이다 [24-27]. 여기 서 $M_{I}$ 의 스케일에 따라서 어떤 일이 일어나는지를 간단히 논의해보자.

먼저 $M_{I}$ 가 대통일 이론의 스케일인 약 $10^{10} \mathrm{GeV}$ 이상일 경우를 보자 [28-31]. 실제로 좌우동형 모델이나 $\mathrm{SO}(10)$ 과 같은 대통일 이론에서는 자연스럽게 시소 과정이 일어날 수 있음이 잘 알려져 있다. 또한 이 경우에는 유카와 결합상수 $F_{\alpha I}$ 가 보통의 결합상수들과 같은 $O(1)$ 의 값을 가질 때, 중성미자의 질량이 현재 예측되는 $\mathrm{eV}$ 이하의 값이 된다. 따라서 수치적으로 가장 자연스럽다. 한편 이 경우에는 암흑물질 문제는 별 해결책이 없다. 또한 $\mathrm{HNL}$ 이 $10^{10} \mathrm{GeV}$ 이상의 질량을 가지게 되므로, 지상의 실험으로 직접 검증할 방법은 없다.

다음으로 $M_{I}$ 가 $\mathrm{TeV}$ 스케일일 경우를 생각한다 [32]. 그렇게 되면 중성미자의 질량을 설명하기 위해서는 $F_{\alpha I}$ 가 $10^{-6}$ 정도여야 한다. 따라서 이 경우 $\mathrm{HNL}$ 을 $\mathrm{LHC}$ 와 같은 가속기에서 직접 생성해서 검증할 수 있는 가능성이 있긴 하지만, 결합상수가 작아서 실제로 생성되거나 검출기에서 검출하는 것은 쉽지 않을 수도 있다. 한편 이 경우에도 암 흑물질을 설명할 수 있는 방법은 따로 없다.

만약 $M_{I}$ 가 $\mathrm{GeV}$ 스케일이면 어떨까? 이럴 경우에 재 미있는 것은 암흑물질을 설명할 가능성이 있다는 점이다.
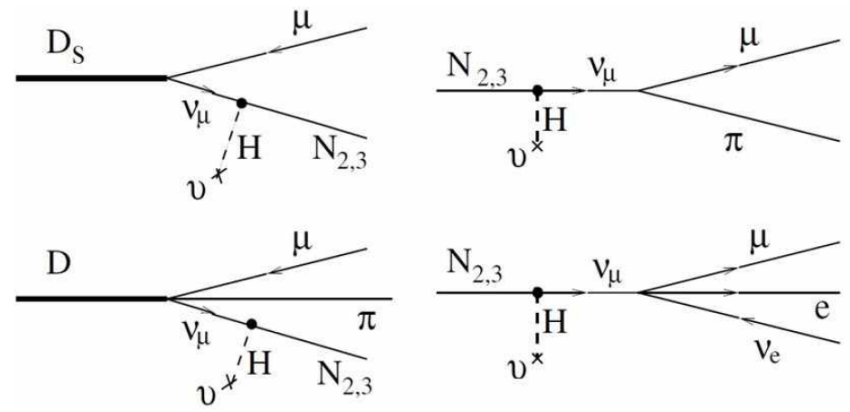

Fig. 7. Productions and decays of the HNL.

만약 세 개의 $\mathrm{HNL}$ 중 가장 가벼운 입자인 $N_{1}$ 이 전자보다 가볍다면, 그 입자는 $N_{1} \rightarrow \nu \gamma$ 등을 통해 중성미자로 붕괴 하는 방법 외에는 달리 붕괴할 방법이 없다. 따라서 입자의 수명이 약 $10^{26}$ 초에 이르게 된다. 또한 $N_{1}$ 은 수십 $\mathrm{keV}$ 의 질량을 가지게 되면 우주의 잔존 밀도 값도 현재의 관측값의 범위에 있다. 따라서 가장 가벼운 $\mathrm{HNL}$ 은 암흑물질이 될 수 있다 [33]. $N_{1}$ 은 $\mathrm{SHiP}$ 에서 검출하기는 어렵지만 천체 물리학적인 관측에서는 검출될 가능성이 있다. 예를 들어, 최근에 은하단에서 방출되는 $3.5 \mathrm{keV}$ 정도의 $\mathrm{X}$-선은 약 7.1 $\mathrm{keV}$ 의 가벼운 암흑물질이 붕괴한 결과로 해석될 수 있다.

또 한 가지 중요한 점은 바로 이 정도의 질량을 가지는 $\mathrm{HNL}$ 이 SHiP 실험의 주요 목표가 될 수 있다는 것이다. $N_{1}$ 을 제외한 나머지 $\mathrm{HNL}$ 은 중성미자를 매개로 생성되고 붕괴할 수 있는데, 만약 이들의 질량이 $\mathrm{GeV}$ 정도고 결합 상수의 크기가 적당하다면 $\mathrm{SHiP}$ 실험의 약 50 미터 길이의 진공 붕괴관에서 뮤온-파이온 쌍 등으로 붕괴할 수 있고, 그렇게 되면 $\mathrm{SHiP}$ 은 이들 입자를 검출할 것이다 [4].

한편 $M_{I}$ 가 더욱 작은 값이라서 약 $\mathrm{eV}$ 정도라면 이제 중성미자와 섞인 정도가 매우 크게 되고, 그러면 우리는 여러 중성미자 실험들, 특히 중성미자의 진동을 측정하는 실험을 통해서 $\mathrm{HNL}$ 을 검증해야 할 것이다.

그러면 이제 $\mathrm{SHiP}$ 실험에서 $\mathrm{GeV}$ 정도의 질량을 가지는 $\mathrm{HNL}$ 을 검출하는 문제를 논의해 보자. $\mathrm{HNL}$ 과 중성미자는 섞임항에 의해 결합하고 있으므로 Fig. 7 에서 보는 바와 같이 $D$ 와 $B$ 메존이 붕괴할 때 생성되고 또한 중성미자와의 섞임을 통해 붕괴한다.

$$
\begin{aligned}
D_{s} \rightarrow \mu \nu_{\mu} \rightarrow \mu N_{2,3} & , \quad D \rightarrow \pi \mu \nu_{\mu} \rightarrow \pi \mu N_{2,3} \\
N_{2,3} \rightarrow \nu_{\mu} \rightarrow \mu \pi & , \quad N_{2,3} \rightarrow \nu_{\mu} \rightarrow \mu e \nu_{e}
\end{aligned}
$$

따라서 $\mathrm{SHiP}$ 에서 이 과정을 관측하는 것은 곧 $\mathrm{HNL}$ 과 중 성미자의 섞임을 관측하는 일이 된다. $N_{2,3}$ 입자들의 붕괴 양식과 그 갈래비는 다음과 같이 주어지는데, 갈래비의 값은 


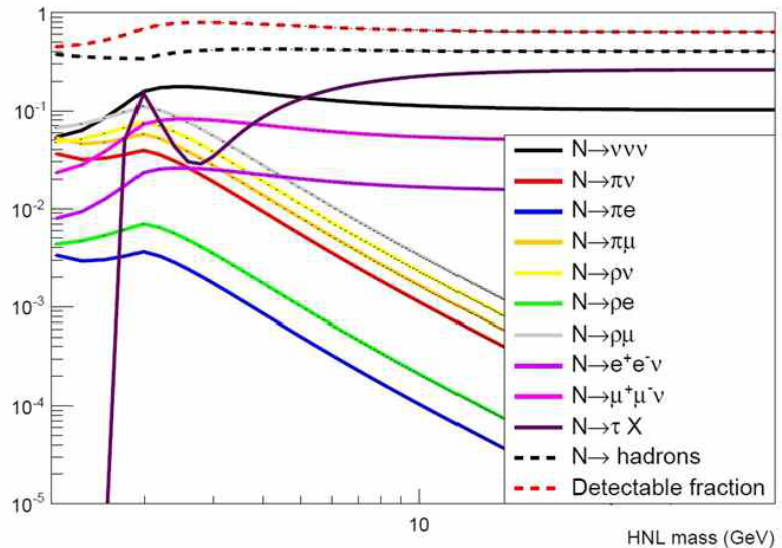

Fig. 8. (Color online) HNL branching ratios as a function of its mass [5].

섞임의 정도에 따라 달라진다 [4].

$$
\begin{aligned}
& B R\left(N \rightarrow \mu^{-} \pi^{+}\right) \sim 0.1-50 \%, \\
& B R\left(N \rightarrow e^{-} \pi^{+}\right) \sim 0.1-50 \%, \\
& B R\left(N \rightarrow \mu^{-} \rho^{+}\right) \sim 0.5-20 \%, \\
& B R\left(N \rightarrow e^{-} \rho^{+}\right) \sim 0.5-20 \%, \\
& B R(N \rightarrow \nu \mu e) \sim 1-10 \%
\end{aligned}
$$

Fig. 8에 $\mathrm{HNL}$ 의 여러 붕괴입자들에 대한 갈래비를 $\mathrm{HNL}$ 의 질량에 따라 나타냈다. 그리고 앞으로 $\mathrm{SHiP}$ 이 관측하게 될 $\mathrm{HNL}$ 의 질량과 중성미자와의 섞임 영역은 Fig. 9 에 보였다.

\section{4. 그 밖의 이론들}

\section{1) 초대칭 입자}

무거운 초대칭 입자는 $\mathrm{LHC}$ 에서 중점적으로 탐색하고 있는 주요 목표 중 하나다. 그런데 특별한 경우에는 초대칭 입자가 작은 질량을 가지고 있지만 아직 $\mathrm{LHC}$ 에서 발견되지 않았으면서 이를 $\mathrm{SHiP}$ 에서 검출할 수도 있다. 그 한 가지 예는 R-parity가 깨어진 경우이다. $\mathrm{SHiP}$ 에서 생성된 $D$ 메 존 (또는 $B$ 메존)이 R-parity를 깨는 항을 통해 붕괴하면서 가벼운 뉴트랄리노가 생성되고, 이어서 뉴트랄리노가 진공 붕괴관에서 붕괴를 하여 케이온과 렙톤 또는 중성미자를 만들어낼 수 있다 [4].

$$
D \rightarrow \widetilde{\chi^{0}}+X \text { 그리고 } \widetilde{\chi^{0}} \rightarrow K+l(\nu) \text {. }
$$

그러면 케이온과 렙톤을 검출하게 된다.

다른 예는 초대칭이 자발적으로 깨어질 때 생기는 골드스 티노의 초대칭 짝인 스칼라 입자 (스골드스티노, sgoldstino)

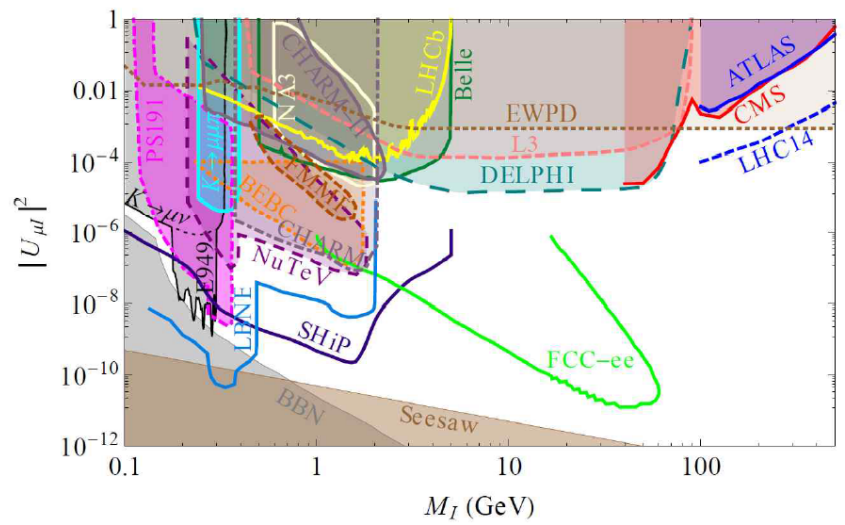

Fig. 9. (Color online) Limits on the mixing between $\nu_{\mu}$ and a HNL [4].

가 가벼운 경우이다. 스골드스티노는 글루온들의 융합을 통하여 바로 생기거나 또는 메존의 붕괴로부터 간접적으로 생길 수 있다. 이어서 렙톤이나 파이온으로 붕괴하기 때문에 검출기에서 찾아낼 수 있다.

그 이외에도 디랙 게이지노가 가벼운 경우라든지, 숨겨진 구역이 초대칭으로 확장된 경우 그 초대칭 짝 입자, 또는 액시노, 중력미자 (gravitino) 등과 같은 초대칭 입자들을 $\mathrm{SHiP}$ 에서 검출할 수 있을 것으로 여겨진다.

2) 액시온같은 입자의 초대칭 짝입자 (Axion-LikeParticle-ino, ALPino)

특히 액시온과 같은 스칼라 입자의 초대칭 짝인 알피노 $(\widetilde{A})$ 는 알려진 구역의 입자들과 아주 약한 상호작용을 하 므로 질량이 작을 때 암흑물질이 될 수 있다. 또한 알피노 역시 질량이 적당한 크기라면 $\mathrm{SHiP}$ 에서 검출할 가능성이 있다. 검출 방법은 다음과 같다. 양성자가 표적에 충돌하여 가벼운 뉴트랄리노 $\left(\widetilde{\chi^{0}}\right)$ 들이 만들어지면, 이어서 뉴트랄 리노는 액시노와 광자, 혹은 렙톤 쌍으로 붕괴한다.

$$
\widetilde{\chi^{0}} \rightarrow \widetilde{A}+\gamma, \text { 또는 } \widetilde{\chi^{0}} \rightarrow \widetilde{A}+l^{+} l^{-} \text {. }
$$

그러면 검출기에서는 광자나 렙톤을 검출하게 된다. 만 약 알피노가 $\mathrm{GeV}$ 정도의 질량을 가지고 있으며, 페차이퀸 (Peccei-Quinn) 스케일 $f_{A}$ 가 $10^{6} \mathrm{GeV}$ 정도라면 이는 $\mathrm{SHiP}$ 실험에서 탐색하기 좋은 영역이다.

\section{III. 숨겨진 입자의 실험적 검증}

여기서 고려하는 숨겨진 입자의 붕괴반응들은 주로 2 개의 하전입자로 붕괴하는 $\mathrm{V}$ 자 형태인데, 그중에서 $\mathrm{SHiP}$ 실험에 
Table 1. Summary of the main decay modes of hidden particles in various models $(l=e, \mu)[5]$.

\begin{tabular}{cc}
\hline \hline Models tested & Final states \\
\hline Neutrino portal, SUSY neutralino & $l^{ \pm} \pi^{\mp}, l^{ \pm} K^{\mp}, l^{ \pm} \rho^{\mp}, \rho^{ \pm} \rightarrow \pi^{ \pm} \pi^{0}$ \\
Vector, scalar, axion portals, SUSY sgoldstino & $l^{+} l^{-}, \pi^{+} \pi^{-}, K^{+} K^{-}$ \\
Neutrino portal, SUSY neutralino, axino & $l^{+} l^{-} \nu$ \\
Axion portal, SUSY sgoldstino & $\gamma \gamma$ \\
SUSY sgoldstino & $\pi^{0} \pi^{0}$ \\
\hline \hline
\end{tabular}

서 가장 선호하는 붕괴는 $\mu^{-} \pi^{+}$이라 할 수 있다. 그 밖에도, 예를 들어 스칼라입자는 $S \rightarrow e^{+} e^{-}, \mu^{+} \mu^{-}, \pi^{+} \pi^{-}, K^{+} K^{-}$ 등으로 붕괴하며, 암흑광자는 $A^{\prime} \rightarrow e^{+} e^{-}, \mu^{+} \mu^{-}, \chi \bar{\chi}$ 등으 로 붕괴하게 된다. 숨겨진 입자들의 종류에 따라 가능한 여 러 가지 붕괴반응을 Table 1 에 정리했다. 데이터를 분석할 때 이론적 모형의 의존성을 최소화하기 위해서 입자확인 (particle identification, PID) 과 검출기에서 붕괴반응들의 전체적인 재구성 (full reconstruction)이 매우 중요하다. $\mathrm{SHiP}$ 의 검출기에는 열량계, 뮤온 검출기, 핵 건판 등을 사 용하는데, 특히 붕괴 후 생성된 입자들을 확인하기 위해서 진공 붕괴관 뒤쪽 부분에 많은 궤적 검출기들을 두어 궤적을 재구성한다.

\section{HNL 검출}

$\mathrm{HNL}$ 을 검출하기 가장 좋은 붕괴 방법은 뮤온과 파이온 으로 붕괴하는 것이다. $\mathrm{SHiP}$ 에서 $N_{2}, N_{3}$ 은 붕괴할 때까지 진공 붕괴관을 통해서 약 $50 \mathrm{~m}$ 를 날아가다가 붕괴한다. 검출기에서는 붕괴 후 만들어진 $\mu$ 와 $\pi$ 입자를 열량계와 뮤온 검출기에 의해 확인하고, 궤적 검출기들에 의해 구성 한 궤적을 이용하여 붕괴 과정의 전체 모습을 재구성하게 된다. 시뮬레이션에 의하면, $D$ 메존에서 발생하는 $\mathrm{HNL}$ 의 특성은 대부분 빔 방향과 $\mathrm{HNL}$ 방향 사이의 각이 매우 작고 ( $20 \mathrm{mrad})$, 재구성된 $\mu$ 와 $\pi$ 입자 궤적의 최단 거리가 2 $\mathrm{cm}$ 이내라는 것이다,

$\mathrm{HNL}$ 의 질량을 $1 \mathrm{GeV}$ 라고 가정할 때, $\mathrm{SHiP}$ 실험에서 검출할 것으로 예상되는 완전히 재구성된 $N_{2,3} \rightarrow \mu^{-} \pi^{+}$사 건의 수는 $U_{\mu}^{2}=10^{-7}, \tau_{N}=1.8 \times 10^{-5} s$ 인 경우에 12,000 개 정도이며, 우주론에서 선호하는 영역인 $U_{\mu}^{2}=10^{-8}$, $\tau_{N}=1.8 \times 10^{-4} s$ 인 경우에는 120 개 정도로 예상된다. 전 자기 열량계에서 $N_{2,3} \rightarrow \mu^{-} \rho^{+}, \rho^{+} \rightarrow \pi^{+} \pi^{0}$ 반응을 검출 한다면 예상 반응수가 2 배로 증가될 수 있으며, 추가적으로 $N_{2,3} \rightarrow e^{-} \pi^{+}$반응도 확인한다면 민감도를 더욱 향상시킬 수 있을 것이다.

과거에 $\mathrm{CERN} \mathrm{PS}$ 가속기에서 $\mathrm{HNL}$ 을 탐색하였던 PS191 실험에서는 입자를 최종적으로 발견하지는 못하
고 [34], Fig. 9 에서 보는 바와 같이 $U^{2}$ 의 한계만 설정하였 다. $\mathrm{CHARM}$ 과 $\mathrm{NuTeV}$ 실험에서도 $\mathrm{HNL}$ 이 최종적으로 $e^{+} e^{-} \nu, \mu^{+} \mu^{-} \nu, e \mu \nu$ 으로 붕괴하는 반응을 탐색하였지만 $\mathrm{HNL}$ 후보반응은 발견되지 않았으며 그림에서 보는 것처럼 $U^{2}$ 의 한계만 정해주었다. 우주론에서 선호하는 바리온 생성, 빅뱅 핵합성 등을 만족하는 값인 $U_{\mu}^{2}=10^{-7} \sim 10^{-9}$ 사이의 영역에서, $\mathrm{SHiP}$ 은 과거 실험들인 PS191, BEBC, CHARM, CCFR, NuTeV 보다 HNL 의 민감도(sensitivity) 를 크게 향상시킬 수 있을 것으로 기대된다.

\section{2. 암흑광자 및 암흑물질 입자의 검출}

앞에서 언급했듯이 암흑광자의 발생 방법으로는 메존들의 전자기적 붕괴, 양성자 제동복사, 직접적인 $\mathrm{QCD}$ 발생의 세 가지를 들 수 있다. 암흑광자의 질량이 2 개의 뮤온 질량보다 작을 때는 대부분 $e^{+} e^{-}$로 붕괴하며, 클 때는 $\mu^{+} \mu^{-}$로 붕괴 하여 주 검출기로 검출할 수 있다. 양성자 제동복사는 $A^{\prime}$ 의 질량이 $400 \mathrm{MeV}$ 와 $\mathrm{GeV}$ 사이일 경우에 중요한 과정이며, 질량이 수 $\mathrm{GeV}$ 이상인 경우에는 직접적인 $\mathrm{QCD}$ 발생과정 이 제일 중요하다. 제동복사에 의해 발생하는 암흑광자는 메존 붕괴에 의해 발생하는 경우에 비해 운동량이 크기 때문에, 암흑광자와 빔 사이의 각이 더 작으며 암흑광자가 진공 붕괴관으로 들어오는 비율이 $80 \%$ 정도로 높다.

특히 암흑광자의 질량이 2 개의 암흑물질 입자의 질량보다 클 때는 $A^{\prime} \rightarrow \chi \bar{\chi}$ 로 붕괴할 수 있다. 이 경우 암흑물질 입자 $\chi$ 가 핵 건판내의 핵자 또는 전자와 탄성 충돌할 수 있는데, 이 때 발생하는 전자들의 에너지가 $\mathrm{GeV}$ 정도인 경우에는 핵 건판에서 확인이 가능하므로 $\mathrm{SHiP}$ 에서는 이러한 반응을 관측하고자 한다. 이러한 $\chi e^{-} \rightarrow \chi e^{-}$반응에서 나오는 전자의 에너지는 $E<20 \mathrm{GeV}$ 정도이며, 방출각은 0.01 $<\theta<0.02 \mathrm{rad}$ 으로 추정된다 [5]. 본 연구진은 과거의 $\mathrm{DONuT}$ 실험에서 $\sim$ 수 $\mathrm{GeV}$ 정도의 전자를 확인하여 $\nu_{e}$ 하전류 (charged current, $\mathrm{CC}$ ) 후보 반응을 82 개 검출한 경험이 있다 $[35,36]$.

이러한 암흑물질 입자와 전자와 탄성 충돌하는 사건의 대표적인 배경입자는 전자 중성미자 반응에 의해 발생하는 

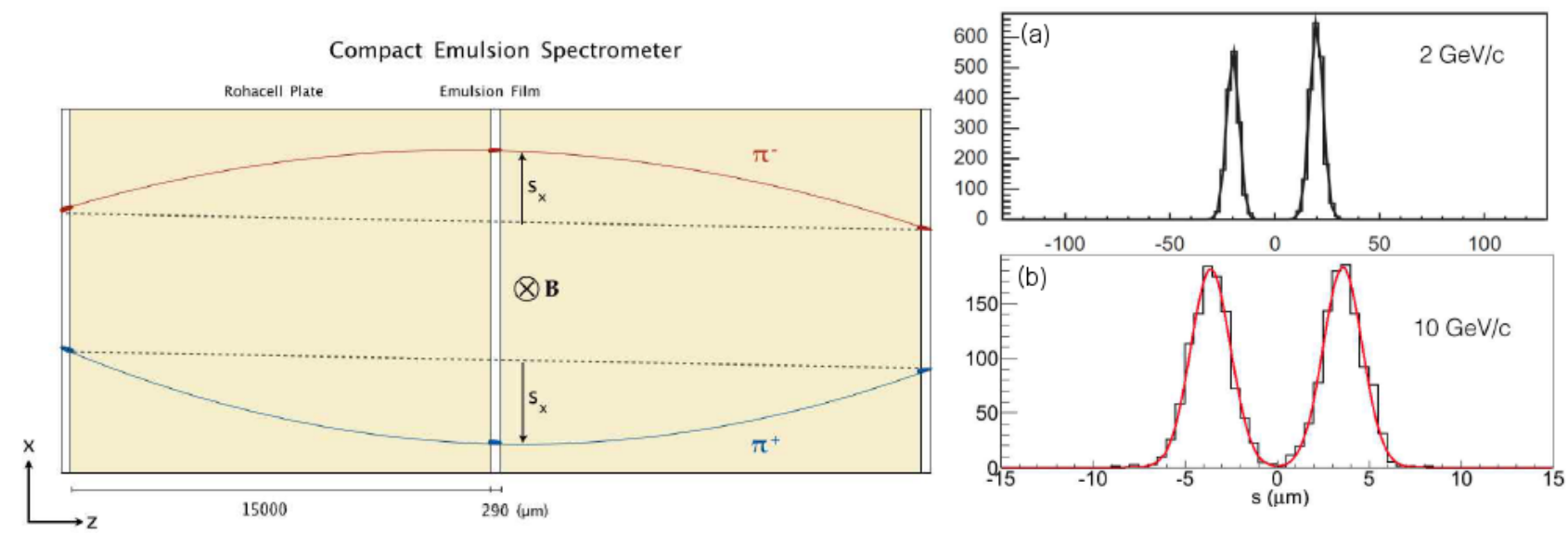

Fig. 10. (Color online) Measured Sagitta distributions of positive and negative pions [Ref] for $2 \mathrm{GeV} / \mathrm{c}$ (data) (a) and $10 \mathrm{GeV} / \mathrm{c}(\mathrm{MC})(\mathrm{b})[5]$.

Table 2. Expected number of $\nu_{\tau}$ and $\overline{\nu_{\tau}}, N^{\text {exp }}$, and charm background events, $N^{b g}$, observed in the different decay channels, except for the $\tau \rightarrow e$, where the lepton number cannot be determined. The signal to background ratio $R$ is also reported [5].

\begin{tabular}{cccccccc}
\hline \hline \multirow{2}{*}{ Decay channel } & \multicolumn{3}{c}{$\nu_{\tau}$} & & \multicolumn{3}{c}{$\overline{\nu_{\tau}}$} \\
\cline { 2 - 4 } \cline { 7 - 8 } & $N^{\exp }$ & $N^{b g}$ & $R$ & & $N^{\exp }$ & $N^{b g}$ & $R$ \\
\hline$\tau \rightarrow \mu$ & 570 & 30 & 19 & & 290 & 140 & 2 \\
$\tau \rightarrow h$ & 990 & 80 & 12 & & 500 & 380 & 1.3 \\
$\tau \rightarrow 3 h$ & 210 & 30 & 7 & & 110 & 140 & 0.8 \\
\hline Total & 1770 & 140 & 13 & & 900 & 660 & 1.4 \\
\hline \hline
\end{tabular}

전자들이다. 현재 이들 배경사건을 구별하는 방법 등, 암흑 광자 및 암흑물질 입자의 검출에 대한 더욱 자세한 연구가 진행 중에 있다.

\section{3. 타우 중성미자 및 반-타우 중성미자 검출}

타우 중성미자는 주로 $D_{s}$ 메존의 붕괴에 의해 만들어 지며, 전자 중성미자나 뮤온 중성미자는 $D^{ \pm}$나 $D^{0}$ 메존의 붕괴에 의해서 생성된다. 이 실험에서 텅스텐-몰리브덴 표 적에 의해 발생하는 타우 중성미자 및 반-타우 중성미자의 예상 개수는 아래와 같이 얻어진다.

$N_{\nu_{\tau}+\overline{\nu_{\tau}}}=4 N_{p} \frac{\sigma_{c \bar{c}}}{\sigma_{p N}} f_{D_{s}} \operatorname{Br}\left(D_{s} \rightarrow \tau\right)=2.85 \times 10^{-5} N_{p}$

여기서 $N_{p}$ 는 총 양성자수이며, $\sigma_{c \bar{c}}=1.8 \pm 1.7 \mu \mathrm{barn}$, $\sigma_{p N}=10.7 \mathrm{mbarn}$ 이고 참 쿼크로부터 $D_{s}$ 메존이 생성 되는 비율은 $f_{D_{s}}=\left(7.7 \pm 0.6_{-0.4}^{+0.5}\right) \%$, 그리고 갈래비는 $\operatorname{Br}\left(D_{s} \rightarrow \tau\right)=(5.5 \pm 0.24) \%$ 이다. 여기서 인자 4는 참
쿼크의 쌍생성과 2 개의 $\nu_{\tau}$ 에 의한 것이며, $N_{p}$ 가 $2 \times 10^{20}$ p.o.t (proton on target) 일 경우 발생하는 타우 중성미자의 수는 $N_{\nu_{\tau}+\overline{\nu_{\tau}}}=5.7 \times 10^{15}$ 로 예상된다.

여러 가지 실험적인 검출 효율 등을 고려하여, 최종적으로 핵 건판 검출기에서 관측할 수 있는 $\nu_{\tau}$ 와 $\overline{\nu_{\tau}}$ 들의 예상 반응 수 $N^{\exp }$ 와 배경입자들의 예상 반응 수 $N^{b g}$ 를 Table 2 에 나타냈다. 여기서 전자들의 전하는 측정하기 어렵기 때문에 $\tau \rightarrow e$ 붕괴의 경우는 제외하였다. 타우입자가 전자로 붕괴 하는 경우 $\nu_{\tau}$ 와 $\overline{\nu_{\tau}}$ 의 총 반응 수는 850 개로 추정되었으며, 배경입자들의 수는 160 개로 예측되었다. 따라서 5 년 동안의 실험에서 핵 건판을 스캔해서 직접 검출할 수 있는 $\nu_{\tau}$ 와 $\overline{\nu_{\tau}}$ 반응의 개수는 총 3520 개이며, 배경입자들의 수는 960 개로 추정된다.

이 실험에서는 표준모형 입자 중에서 아직까지 직접적으 로 발견되지 않은 유일한 입자인 반-타우 중성미자를 검출 할 수 있다. 타우 중성미자와 반-타우 중성미자는 이들이 만드는 타우입자가 붕괴할 때 나오는 뮤온의 전하를 측정 해서 구별할 수 있다 $\left(\nu_{\tau} \rightarrow \tau^{-} \rightarrow \mu^{-}, \overline{\nu_{\tau}} \rightarrow \tau^{+} \rightarrow \mu^{+}\right)$. 뮤온의 전하를 측정하기 위해서 CES (Compact Emulsion Spectrometer) 와 자석을 사용한다. CES는 핵 건판 필름 사이에 밀도가 낮은 벌집구조를 넣어 필름과 필름 사이의 간격을 크게한 일종의 궤적 검출기이다. 잘 알려진 대로 하전입자의 전하는 자기장에 의해 휘어지는 방향으로 알 수 있는데, 그림에서 보는 바와 같이 테스트 실험에서 파이 중간자의 경우 Fig. 10 에서 측정된 S 값이 0 을 중심으로 좌 (-) 우 $(+)$ 로 잘 분리됨을 볼 수 있다.

그 밖에도 $\mathrm{SHiP}$ 실험에서는 타우 중성미자와 반-타우 중성미자의 반응단면적과 자기모멘트 등을 측정할 것이며, 특히 아직 실험적으로 측정되지 않았던 타우 중성미자가 깊은 비탄성충돌을 할 때 반응단면적의 구조함수 (structure 


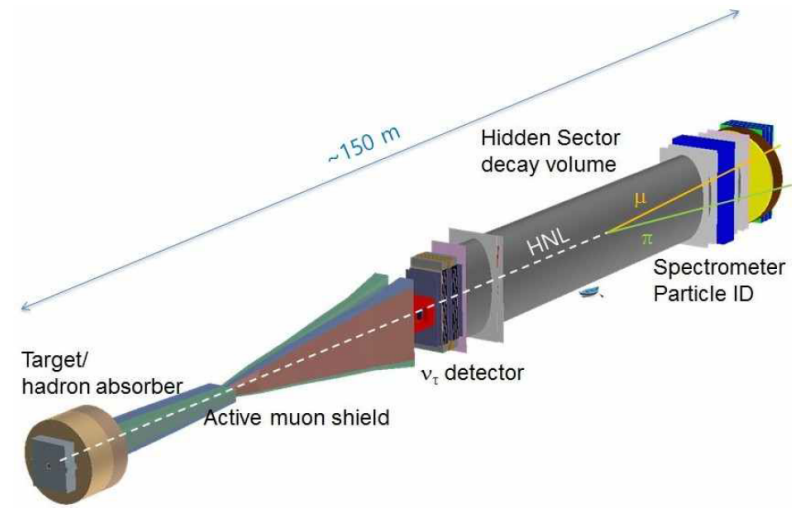

Fig. 11. (Color online) Overview of the SHiP facility [5].

function) F4, F5를 측정할 수 있을 것이다. SPS 가속기의 $400 \mathrm{GeV}$ 양성자 빔을 사용하는 $\mathrm{SHiP}$ 실험은 타우 중성미자 의 성질을 연구할 수 있는 현존하는 최적의 실험이다. 또한 타우 중성미자 뿐 아니라, 전자 중성미자나 뮤온 중성미자 에 의한 참 쿼크의 발생도 체계적으로 연구하는 등, 모든 종류의 중성미자-반 중성미자 물리에 대한 정보도 얻을 수 있을 것으로 기대하고 있다.

\section{IV. 실험장치}

\section{1. 가속기 빔 및 실험장치 개관}

$\mathrm{SHiP}$ 실험은 CERN SPS 가속기의 $400 \mathrm{GeV}$ 빔을 사 용하며, 빔 라인과 실험시설은 과거의 CHORUS 실험이 수행되었던 북쪽 지역 (North area)에 건설될 예정이다. 5 년 동안 $2 \times 10^{20}$ p.o.t 을 달성한다면 $10^{17}$ 개의 $D$ 메존, $10^{14}$ 개의 $B$ 메존, $10^{15}$ 개의 타우 입자들을 만들 수 있다 [5].

Fig. 11에 SHiP 실험장치의 전체 모습을 보였다. 표적은 단면적이 $30 \times 30 \mathrm{~cm}^{2}$, 길이가 $120 \mathrm{~cm}$ 인 몰리브덴이 첨가 된 티타늄-지르코늄 블록과 텅스텐 블록으로 이루어진 정지 표적을 사용한다. 이렇게 원자번호가 큰 복합적인 표적은 참 하드론으로부터 발생하는 중성미자를 최대로 만들고, $\pi$, $K$ 메존으로부터 발생하는 중성미자는 최소가 되게 하려는 것이다.

표적 뒤에는 $5 \mathrm{~m}$ 두께의 철로 되어있는 하드론 흡수체 (hadron absorber) 가 놓여서, 양성자 빔이 정지표적과 충돌 하여 다량 발생하는 $\pi, K$ 메존들을 흡수한다. 그 다음에 $\pi$, $K$ 메존들이 붕괴할 때 발생하는 뮤온들이 숨겨진 입자 검출 기로 진입하지 못하도록, 강력한 자석을 사용하여 뮤온들의 경로를 바꾸게 만드는 뮤온 차폐 장치가 위치하는데, 현재

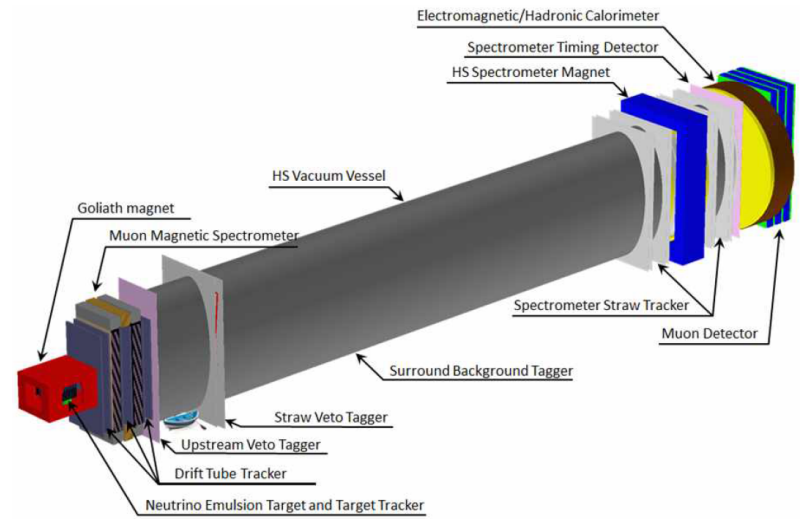

Fig. 12. (Color online) The SHiP detector layout [5].

여기에 초전도 자석의 사용도 고려중이다. 그 다음에는 핵 건판으로 이루어진 타우 중성미자 검출기가 놓인다.

다음은 숨겨진 입자를 검출하기 위한 장치다. 먼저 숨겨 진 입자들이 붕괴를 할 수 있는 $50 \mathrm{~m}$ 의 진공 붕괴관이 있고, 마지막에는 궤적 검출기, 열량계, 자석 그리고 뮤온 검출기 로 이루어진 검출기가 위치해서, 숨겨진 입자들이 붕괴해서 나온 최종 입자들의 종류를 확인하고 궤적을 재구성하게 된다. 그리고 시간 검출기 (timing detector) 도 설치하여 우 연히 V자처럼 생긴 (random crossing) 궤적들을 제거하는 데 도움을 준다.

\section{2. 입자검출기}

입자검출기는 크게 숨겨진 입자 검출기와 타우 중성미 자 검출기로 나눌 수 있다. 검출기 부분의 자세한 모습을 Fig. 12 에 보였다 [5].

\section{1) 숨겨진 입자 검출기}

숨겨진 입자들은 표준모형 입자들과 매우 약하게 결합 하며 $\left(\sim 10^{-10}\right)$, 수명이 길고, 질량이 비교적 작으며, 매우 드물게 발생하는 것이 특징이다. 따라서 숨겨진 입자들을 검출하기 위해서는 길이가 충분히 긴 검출기가 필요하다. $\mathrm{SHiP}$ 실험에서 설계한 숨겨진 입자 검출기의 길이는 $62 \mathrm{~m}$ 인데, 진공 붕괴관이 $50 \mathrm{~m}$, 스펙트로미터 길이가 $12 \mathrm{~m}$ 이다.

진공 붕괴관 속의 공기와 중성미자의 충돌을 최소한으로 하기위해서 진공관의 진공을 $10^{-6} \mathrm{bar}$ 로 할 계획이다. 진 공 붕괴관 뒤에는 숨겨진 입자들의 붕괴입자들을 검출하기 위한 검출장치가 놓여있는데, 궤적 검출기, 열량계와 자석, 그리고 뮤온 검출기들로 이루어져있다. 이러한 검출기들의 역할은 다음 같다. 
1) 입자확인 - 전자기 열량계, 하드론 열량계, 핵 건판, 뮤온 검출기들에서 $\pi, \mu, e, \gamma$ 의 입자들을 확인하게 된다. 뮤온 검출기는 핵 건판 뒤에 하나 위치하고, 숨겨진 입자 검출기의 열량계 뒤에도 설치된다.

2) 위치측정에 의한 궤적의 재구성 - 표적 궤적 검출기 (target tracker, TT), 스트로 트랙커 (straw tracker), 흐름 관 (drift tube), 핵 건판에 의해서 충돌 및 붕괴 후에 발생하 는 입자들의 위치를 측정하여 입자들의 궤적을 재구성하게 된다. $5 \mathrm{~m}$ 길이의 스트로 트랙커는 4 개의 층으로 이루어져 있으며, 그 사이에 자석이 들어있고 $120 \mu \mathrm{m}$ 정도의 공간 분해능을 가진다. 광섬유로 되어 있는 TT는 핵 건판 바로 뒤에 위치해 있으며, 궤적의 위치뿐만 아니라 각도 정보를 제공해준다. DT는 OPERA 실험에서 쓰던 것을 재활용할 예정이다.

3 ) 전하 및 운동량 측정 - 자석을 동반한 ECC (Emulsion Cloud Chamber), CES와 뮤온 검출기에 의해 하드론과 뮤온의 전하와 운동량 측정이 가능하다.

4) 시간 측정 -2 개의 뮤온 입자가 우연히 교차되는 배 경입자를 제거하기 위해서는 시간정보가 필요하다. 이를 위해 $100 \mathrm{ps}$ 정도의 시간분해능이 요구되는데, $\mathrm{CERN}$ 의 NA61/SHINE 실험과 COMPAS 실험에서 사용되었던 신 틸레이팅 바 (scintillating bar) 와 ALICE 실험에서 쓰였던 $\mathrm{MRPC}$ 중에서 어느 것을 사용할지 고려 중이다. 그리고 $\mathrm{TT}$ 와 열량계에 의해서도 시간정보를 얻을 수 있는데, TT 는 중성미자 반응의 시간 도장 (time stamp) 를 찍는 역할을 한다.

숨겨진 입자들의 배경입자들은 주로 오래 사는 중성입자 들이다. 이들은 주로 Table 3 과 같이 중성미자들 및 뮤온 들의 반응에 의해 발생하는 $K_{L}^{0}$ 과 같은 $\mathrm{V}$ 자 모양의 입자들 이다. 여기서 $N$ 은 핵자다. 이러한 배경입자들과 신호입자 들을 구별하기 위해서는 입자들의 종류를 확인하고 궤적을 재구성하는 것이 매우 중요하며, 배경입자들이 검출기내에 들어오지 못하게 실험 장치를 설계하는 것이 효과적이다. 강한 자기장에 의해서 뮤온 입자들의 경로가 바뀌었음에도 불구하고 살아남은 뮤온 입자나 중성미자들을 걸러내기 위 해서 숨겨진 입자 검출기 바로 앞에 상류 배경입자 제거용 검출기 (upstream veto tagger)를 설치할 예정이다. 여기 에는 시간분해능이 $1 \mathrm{~ns}$ 이고 크기가 $4 \times 12 \mathrm{~m}^{2}$ 플라스틱 신틸레이션 바를 사용할 예정이다.

진공 붕괴관의 단면은 장반경 $10 \mathrm{~m}$, 단반경 $5 \mathrm{~m}$ 의 타원 모양으로 자기장에 의해 휘어지는 뮤온 선속들을 피하기 위한 구조이다. 진공 붕괴관을 둘러싸고 있는 배경입자 검출기는 바깥으로부터 들어오는 배경입자들을 제거하는 역할을 한다. 이를 위해 진공 붕괴관의 껍질을 2 중으로 만들어 그 사이의 $30 \mathrm{~cm}$ 공간에 액체 신틸레이터를 주입 하고 광센서 (wavelength-shifting optical module, WOM) 를 연결할 예정이다.
Table 3. List of background sources with $V^{0}$ particles $[5]$.

\begin{tabular}{cc}
\hline \hline Background Source & Decay modes \\
\hline$\nu$ or $\mu+N \rightarrow X+K_{L}$ & $K_{L} \rightarrow \pi e \nu, \pi \mu \nu, \pi^{+} \pi^{-}, \pi^{+} \pi^{-} \pi^{0}$ \\
$\nu$ or $\mu+N \rightarrow X+K_{S}$ & $K_{S} \rightarrow \pi^{+} \pi^{-}, \pi^{0} \pi^{0}$ \\
$\nu$ or $\mu+N \rightarrow X+\Lambda$ & $\Lambda \rightarrow p \pi^{-}$ \\
$n$ or $p+N \rightarrow X+K_{L}$, etc. & as above \\
\hline \hline
\end{tabular}

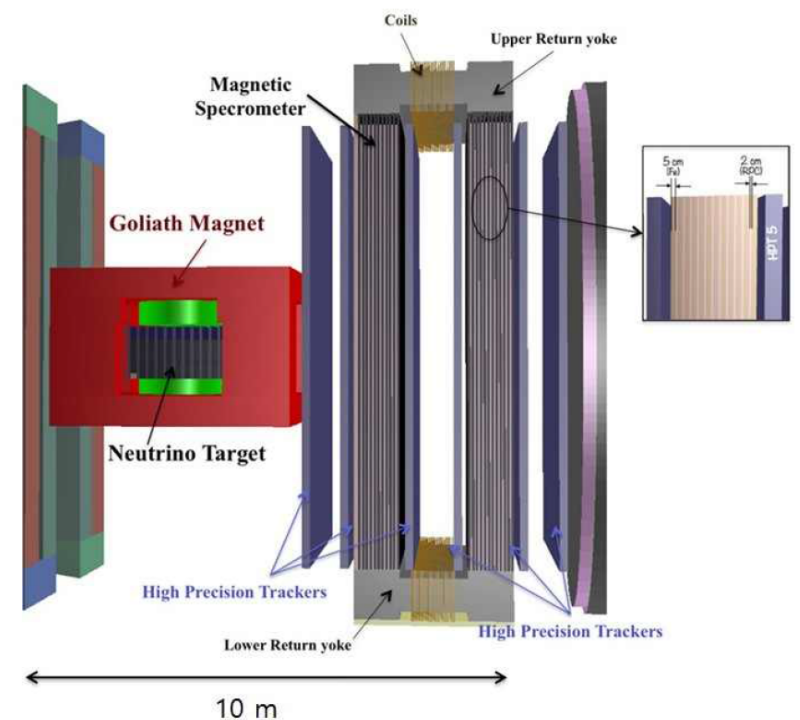

Fig. 13. (Color online) Zoomed view of the tau neutrino detector [5].

\section{2) 타우 중성미자 검출기}

현재까지 발견된 타우 중성미자들의 수는 DONuT 실험 에서 9 개 [35,36], OPERA 실험에서 5 개에 불과하다 [37]. 타우입자는 붕괴할 때까지 날아가는 길이가 매우 짧기 때문 에 $(c \tau \sim 87 \mu \mathrm{m})$, 궤적을 확인하기 위해서는 공간 분해능이 $1 \mu \mathrm{m}$ 이하인 원자핵 건판 검출기가 필요하다.

원자핵 건판은 공간분해능이 다른 검출기들에 비해 월등 히 뛰어날 뿐 아니라, 표적 $(\mathrm{H}, \mathrm{C}, \mathrm{N}, \mathrm{O}, \mathrm{Ag}, \mathrm{Br})$ 인 동시에 3 차원적인 반응의 모습을 직접 볼 수 있는 $3 \mathrm{D}$ 검출기이다. 최근 자동 스캐닝 장치와 넷스캔 (Net scan) [38]이라는 새로운 오프라인 분석법의 개발로 인하여 다량의 데이터를 신속하게 처리할 수 있을 뿐 아니라, 건판내의 궤적만으로 도 입자의 구별 (전자와 하드론 등) 이 가능하고 운동량을 측정할 수 있다. 또한 반응을 재구성할 수 있는 매우 정밀한 궤적 검출기의 역할도 할 수 있어 최근에는 중성미자 실험 등에 많이 사용되고 있다.

$\mathrm{SHiP}$ 실험의 타우 중성미자 검출기는 $10 \mathrm{~m}$ 정도 길이로 $\mathrm{ECC}$ 브릭과 $\mathrm{CES}$, 그리고 $\mathrm{TT}$, 뮤온 분광계 등으로 이루어 져있다. ECC 브릭들 뒤에는 중성미자 반응에 의해 발생하 
Table 4. Branching ratio for different $\tau$ decay channels.

\begin{tabular}{cc}
\hline \hline Decay channel & Branching ratio \\
\hline$\tau^{-} \rightarrow e^{-} \nu_{\tau} \overline{\nu_{e}}$ & $17.8 \%$ \\
$\tau^{-} \rightarrow \mu^{-} \nu_{\tau} \overline{\nu_{\mu}}$ & $17.7 \%$ \\
$\tau^{-} \rightarrow h^{-} \nu_{\tau}\left(n \pi^{0}\right)$ & $49.5 \%$ \\
$\tau^{-} \rightarrow h^{+} h^{-} h^{-} \nu_{\tau}\left(n \pi^{0}\right)$ & $15.0 \%$ \\
\hline \hline
\end{tabular}

는 뮤온 입자의 위치와 시간에 대한 정보를 제공해주는 TT 가 있으며, 그 뒤에는 뮤온 입자의 확인과 운동량을 측정해 주는 뮤온 분광계가 놓여 있다. Fig. 13 에 타우 중성미자 검출기의 개관을 보였다.

$\mathrm{TT}$ 의 정보에 따라 중성미자 반응이 있을 것으로 예상되 는 지점 부근의 브릭 $1 \sim 3$ 개를 선택해서 꺼내고 그 자리에 는 새 브릭을 채운다. 꺼낸 브릭의 맨 뒤쪽 (하류 쪽) 에는 특수한 핵 건판 필름인 CS (changeable sheet) 가 있는데, 우선 이것을 먼저 스캐닝하게 된다. 스캐닝 결과, 만일 $\mathrm{TT}$ 에 의해 예측된 궤적이 없다면 그 브릭은 새로운 $\mathrm{CS}$ 를 부 착하여 다시 표적으로 재사용한다. 만일 예측된 궤적이 CS 에서 발견되면 그 브릭은 곧 차폐된 공간에 저장되며, 핵 건판 정렬을 위해서 X-ray 조사를 하게 된다. 그리고 운동량 측정을 위해 우주선 조사를 마친 후 현상하여 중성미자 반응 점을 찾기 위해 $\mathrm{ECC}$ 를 스캐닝한다. 즉, $\mathrm{CS}$ 는 $\mathrm{TT}$ 와 $\mathrm{ECC}$ 사이에 궤적을 연결하는 인터페이스 역할을 한다고 볼 수 있다.

$\mathrm{ECC}$ 표적은 1970년대 우주선 실험 [39]과 2000 년대 $\mathrm{DONuT}[35,36], \mathrm{OPERA}$ 실험 [37]에서 각각 참 쿼크 입자 와 타우 중성미자 반응을 최초로 관측하는 데 사용되었다. $\mathrm{SHiP}$ 실험에서도 거의 같은 구조의 $\mathrm{ECC}$ 브릭을 사용할 예정이다.

OPERA 실험에서 사용된 ECC는 Fig. 14에서 보는 대로 원자핵 건판 필름과 $1 \mathrm{~mm}$ 두께의 납판을 샌드위치 구조로 배열해 놓았다. 마치 벽돌처럼 생겼다고 해서 ' $\mathrm{ECC}$ 브릭' 이라고 부른다. 한 개의 브릭은 57 장의 핵건판 필름과 56 장의 납판으로 구성되어 있으며, 가로 $12.5 \mathrm{~cm}$, 세로 $10 \mathrm{~cm}$, 두께가 $7.54 \mathrm{~cm}$ 그리고 무게가 $8.2 \mathrm{~kg}$ 이다. 이것은 약 10 $X_{0}$ (radiation length)에 해당한다. 이렇게 핵 건판 필름사 이에 납판을 적층시키는 이유는 첫째, 중성미자 반응을 많이 만들 수 있으며, MCS (Multiple Coulomb Scattering) 방 법으로 $\mathrm{ECC}$ 를 통과한 입자들의 운동량을 측정할 수 있기 때문이다.

$\mathrm{SHiP}$ 실험에서는 12 개의 $\mathrm{TT}$ 층 사이에 $\mathrm{ECC}$ 브릭과 $\mathrm{CES}$ 들이 채워져 있는데, 타우 중성미자 표적의 전체 단면 적은 $2 \mathrm{~m}$ (가로) $\times 1 \mathrm{~m}$ (세로) 정도이며, 빔 방향의 총길 이는 $2 \mathrm{~m}$ 정도로 예상하고 있다. Fig. 15 에 ECC 브릭과 $\mathrm{CES}$ 에 기록된 타우 중성미자 사건의 한 예를 보였다.

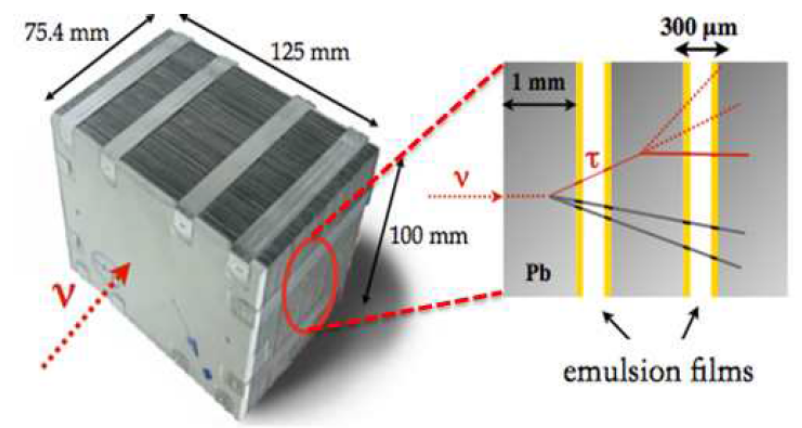

Fig. 14. (Color online) ECC brick.

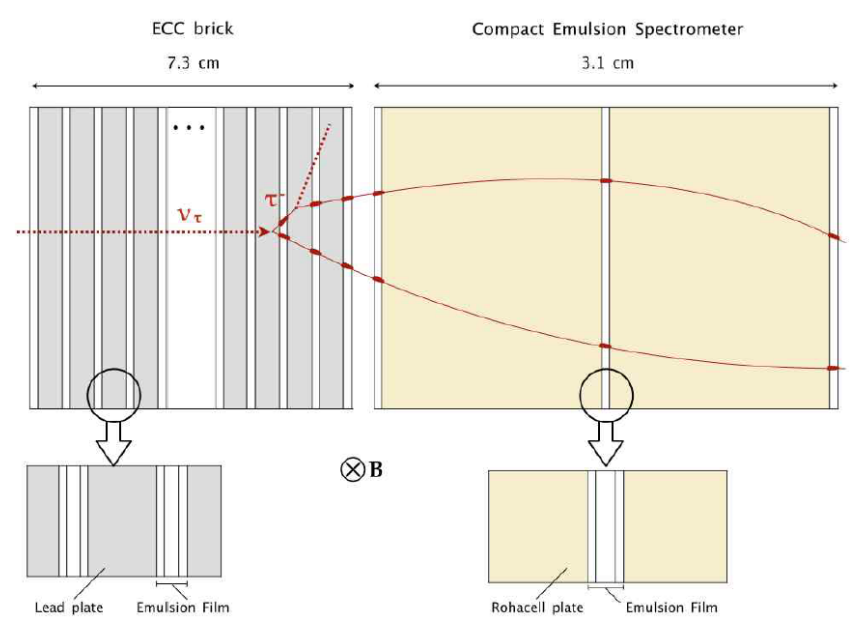

Fig. 15. (Color online) Tau neutrino event in the ECC brick and CES [5].

\section{3. 타우 중성미자 CC 반응 확인방법}

타우 중성미자 $\nu_{\tau}$ 는 $\mathrm{ECC}$ 표적과 반응하여 타우입자 $\tau^{-}$ 를 만든다. 만들어진 $\tau^{-}$입자의 붕괴 갈래비는 Table 4 에서 보는 바와 같이 뮤온, 전자, 또는 하드론으로 붕괴하는 킹크 붕괴 (kink decay) 가 약 $85 \%, 3$ 개의 하드론으로 붕괴하는 트라이던트 붕괴 (trident decay) 가 $15 \%$ 정도이다. 만일 $\mathrm{ECC}$ 표적에서 이러한 타우입자의 붕괴반응을 찾는다면 타우 중성미자 반응이라고 확인할 수가 있다.

타우붕괴의 배경사건은 주로 참 입자의 붕괴나 하드론의 탄성충돌이다. 이런 배경입자들을 제거하고 타우입자임을 확인하기 위해서 다음과 같은 운동학적 조건을 요구한다.

1 차 반응 (중성미자 반응) 점에서의 조건들 :

i) 뮤온이나 전자의 비적이 없어야한다 (만일 있다면 $\nu_{\mu}, \nu_{e} \mathrm{CC}$ 반응임).

ii ) 손실된 수직운동량 $\left(P_{T}^{m i s s}\right)$ 이 $1 \mathrm{GeV} / \mathrm{c}$ 보다 작아야 한다.

iii) 하드론들의 평균방향과 타우 입자사이의 방위각 (azimuthal angle) $\Phi$ 가 $90^{\circ}$ 이상이 되어야한다. 
2 차 반응 (타우입자 붕괴) 점에서의 조건들 :

i) 킹크각이 $20 \mathrm{mrad}$ 보다 커야한다.

ii ) 붕괴점이 중성미자 반응점으로부터 2 개의 납판 $(1 \mathrm{~mm}$ 두께)이내에 있어야 한다.

iii) 2 차 입자의 운동량 $2 \mathrm{GeV} / \mathrm{c}$ 이상이어야 한다

iv) 붕괴된 입자의 수직 운동량 $\mathrm{Pt}$ 가, 붕괴점에서 광자 가 발생하지 않는 경우에 $600 \mathrm{MeV} / \mathrm{c}$ 이상이 되어야 하며, 광자가 발생하는 경우는 $300 \mathrm{MeV} / \mathrm{c}$ 이상이 되어야 한다.

\section{V. 한국 그룹 소개}

\section{1. 한국 그룹의 결성 및 활동}

한국 $\mathrm{SHiP}$ 그룹은 $\mathrm{CERN}$ 에서 만든 중성미자를 이탈리아 그랑 사소 연구소에서 검출하는 실험인 OPERA 실험에 참 여했던 연구진들을 중심으로 2015 년에 결성되었다. SHiP 의 타우 중성미자 검출 부분은 OPERA 의 검출기와 거의 같은 핵 건판-스펙트로미터 복합장치를 이용하기 때문에 $\mathrm{SHiP}$ 실험은 타우 중성미자 연구부분에서는 OPERA의 후속 실험이라고 할 수 있다. 2015 년 7 월에 CERN에서 열린 $\mathrm{SHiP}$ 공동연구자 회의에서 경상대학교는 $\mathrm{SHiP}$ 실험 의 정식 멤버로 참여할 것을 승인받았다. 그리고 2016 년 2 월 초 $\mathrm{CERN}$ 에서 열린 회의에서는 제주대학교, 전남대 학교와 광주교육대학교가 준멤버 (associate member) 로 참가하는 것이 결정되었다. 따라서 한국그룹은 현재 4 개 대학 (경상대, 제주대, 전남대, 광주교대), 9 명의 연구원으로 구성되어있다. 현재까지 한국 그룹은 $\mathrm{SHiP}$ 의 공동연구자 회의에 꾸준히 참가하고 있으며, 국내에서는 약 2 개월마다 워크숍을 열고 실험에 참여하는 방법과 주제를 논의하고 있다.

\section{2. 한국 그룹의 연구내용}

실험 면에서 한국 그룹이 주력하는 부분은 타우 중성 미자를 검출하는 핵 건판 부분이다. 이미 CHORUS 실험, OPERA 실험과, 그 이전의 DONuT 실험 등을 통해서 많은 경험을 축적해왔기 때문이다. 그동안 한국 그룹은 핵 건판 실험분야에서 세계 최대의 그룹인 일본 나고야 대학과 밀 접한 관계를 유지하며 공동연구를 수행해 왔다. 한편 올해 8 월의 CERN PS 및 SPS 의 테스트 빔 기간에 한국그룹은 포토마스크 (photomask) 를 제작하여 CERN 에서 핵 건판 정렬에 대한 연구에 참여했다.

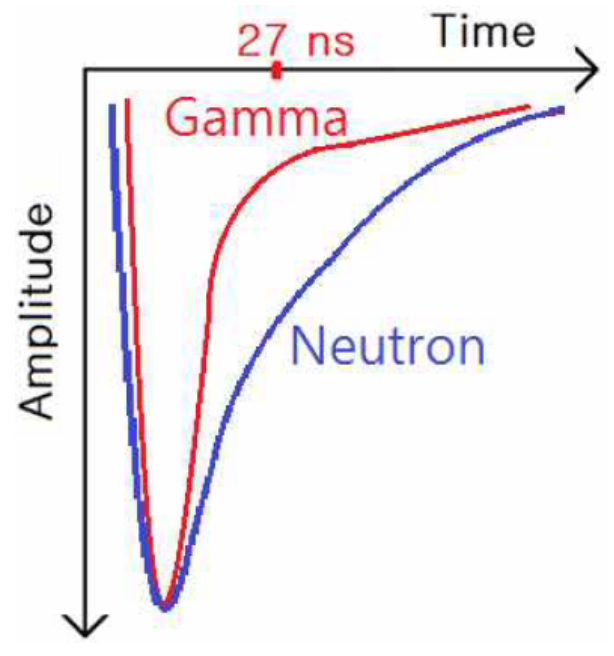

Fig. 16. (Color online) PSD of gamma ray as a typical MIP and neutron as a typical HIP.

한편 한국 그룹은 $\mathrm{SHiP}$ 에서 암흑물질을 직접 측정하는 방법으로 파형판별법 (pulse shape discrimination, PSD) 을 준비하고 있다. PSD는 표준모형의 입자와 매우 약하게 상호작용을 하고 전기적으로 중성인 암흑물질을 측정하는 방법으로서 가능성이 있다. $\mathrm{PSD}$ 의 작용원리는 암흑물 질의 유력한 후보인 WIMP (weakly interacting massive particle) 입자를 측정하는 작용원리와 유사하고 이런 방 법들은 이미 수십 년 전부터 연구되어 온 매우 안정적인 방법이다 [40-43].

암흑물질은 질량이 있는 입자이므로 암흑물질이 표적이 되는 원자핵과 탄성충돌해서 발생하는 섬광들을 광전증배기 (photomultiplier tube, PMT) 로 검출했을 때 나타나는 파 형은 중성자가 섬광물질을 구성하는 핵자인 표적핵과 탄성 충돌해서 발생하는 신호의 파형과 유사하다. 중성자, 알파 입자, 암흑입자 등은 무거운 이온화 입자 (heavy ionization particle, HIP) 로 분류하고, 광자 등은 최소 이온화 입자 (minimum ionization particle, MIP) 로 구별한다. Fig. 16 은 입사입자가 MIP인 경우와 HIP 인 경우 파형의 모습을 보여주고 있다. 뮤온, 파이온, 전자 등의 하전입자들도 표 적핵과의 탄성산란에 의해 발생한 신호를 이용해서 파형 판별로 구별할 수 있지만, 하전입자는 궤적검출기 등으로 더욱 쉽게 판별되므로 PSD 방법은 보조적으로 사용하는 것으로 충분하다.

$\mathrm{SHiP}$ 실험에서 한국그룹이 담당할 연구내용은 주로 다 음과 같다.

1. 핵 건판 관련 연구 : grid mark 를 사용한 의한 핵 건판 정렬 및 스캐닝 등.

2. 암흑물질 연구 : 암흑광자의 붕괴에 의해 발생하는 암흑물질 탐색 - 핵 건판, PSD 방법. 
3. 슈퍼컴퓨터를 이용한 연구 : 시뮬레이션 등.

4. 데이터 분석 : 숨겨진 입자 및 타우 중성미자 탐색.

5. 기타 이론적 연구 : 암흑 스칼라 입자, 액시노 등.

이러한 연구 내용을 바탕으로 한국 그룹은 올해 안으로 $\mathrm{CERN}$ 과 $\mathrm{CDR}$ 단계의 $\mathrm{MoU}$ 를 체결할 예정으로 있다.

\section{VI. 실험의 전망 및 결론}

\section{1. 경과 및 앞으로의 계획}

$\mathrm{SHiP}$ 은 2013 년경부터 논의가 시작되어, 2015 년 4 월에 물리적 제안서와 기술적 제안서를 CERN SPS 가속기 위원 회 (SPSC) 에 제출하였다. 2016년 1월에 받은 답변에 따르 면 위원회는 $\mathrm{SHiP}$ 실험에 대해 매우 긍정적으로 평가하고 있으며, 실험 전반과 구체적인 설계를 담은 Comprehensive Design Report (CDR)를 작성할 것을 권하고 있다.

CERN 연구위원회 (Research Board)는 SPSC 결정을 지지하였으며, 최근에 $\mathrm{CERN}$ 에서 결성된 충돌장치 다음의 물리학 연구그룹 (Physics Beyond Colliders Study Group) 의 연구와 보조를 맞추어 $\mathrm{CDR}$ 의 내용이 유럽 입자물리학 계획 (European Strategy of Particle Physics) 에 수록될 수 있도록 추진하라고 제안하였다. 이를 위해 현재 각 검출 기들의 최적화와 민감도 향상을 위해 집중적으로 연구하고 있다.

$\mathrm{SHiP}$ 실험은 현재 16 개국 47 개 기관의 250 여명의 연 구자들이 참여하고 있으며, 영국 임페리얼 컬리지 런던 (Imperial College London)/CERN의 안드레이 골루트빈 (Andrey Golutvin)이 대표(spokesperson)를 맡고 있다.

앞으로 예상되는 $\mathrm{SHiP}$ 실험의 중장기적인 스케줄은 다음 과 같다. 우선 올해부터 3 년 동안 $\mathrm{CDR}$ 을 작성하게 된다. 이를 위해 PS 및 SPS의 테스트 빔을 사용한 예비실험을 수행하여 검출기들의 구조와 실험 장치들의 디자인을 최적 화한다. 이후 공식적으로 실험이 승인되면 2021년부터 5년 예정으로 빔 라인 토목공사에 들어갈 것이며, 그와 병행해서 4 년여 동안의 검출기 제작과 2 년여 동안의 검출기 설치 및 시험가동을 통한 성능평가를 할 예정이다. 그리고 $\mathrm{LHC}$ 의 3 차 장기 휴지기 (LS3)가 끝나고 $\mathrm{LHC} 4$ 차 가동이 시작 되는 2026 년부터 SPS 빔을 받아서 데이터를 얻기 시작할 예정이다.

\section{VII. 맺음말}

$\mathrm{SHiP}$ 실험은 지금까지 인간이 아직 탐구하지 않은 영 역을 자세히 연구하고자 하는 '더 많은 입자를 추구하는' 실험 중에서 가장 최신의 아이디어와 기술을 집약하고자 하는 실험이다. 그런 의미에서 이 실험은 $\mathrm{LHC}$ 와 상보적인 역할을 할 것이다. 특히 이 실험은 몇몇 이론적 모형에서 우주의 바리온 대칭성과 빅뱅 핵합성 등을 설명할 수 있는 우주론적으로 흥미 있는 매개변수 영역을 검증할 수 있다. 이러한 실험으로서 에너지와 빔의 광도를 고려할 때 현재 가장 이상적인 시설은 $\mathrm{CERN}$ 의 $\mathrm{SPS}$ 가속기이며, $\mathrm{SHiP}$ 은 바로 $\mathrm{SPS}$ 를 이용하는 실험이다. $\mathrm{SHiP}$ 은 $\mathrm{CERN}$ 이 미래를 위해 준비하는 실험 중에서도 가장 중요한 실험 중 하나로 꼽히고 있으므로 머지않은 장래에 공식적으로 승인되어 정식으로 출범하게 될 것으로 예상된다. 한국 그룹은 $\mathrm{SHiP}$ 이 아직 정식으로 출범하기 전인 초기 단계에 실험에 합류했 으므로, 앞으로 실험의 회원국으로서 실험에 중요한 기여를 할 수 있을 것이며, 또한 이와 관련해서 한국의 입자물리학 발전에도 크게 기여할 것이다.

\section{감사의 글}

본 논문은 $\mathrm{SHiP}$ 실험의 제안서 (proposal) 를 기반으로 작성한 개괄논문으로서, 한국연구재단 NRF-2016R1A2B4 012302(최기영), NRF-2015R1A2A2A01004532(이강영), NRF-2013R1A1A2063641(우종관), NRF-2013R1A1A20 61654 (윤천실) 의 지원을 받아 수행되었습니다.

\section{REFERENCES}

[1] G. Aad, T. Abajyan, B. Abbott, J. Abdallah and S. A. Khalek et al., [ATLAS Collaboration], Phys. Lett. B 716, 1 (2012).

[2] S. Chatrchyan, V. Khachatryan, A. M. Sirunyan, A. Tumasyan and W. Adam et al., [CMS Collaboration], Phys. Lett. B 716, 30 (2012).

[3] SHiP official webpage, http://ship.web.cern.ch/ ship (accessed Aug. 24, 2016).

[4] S. Alekhin, W. Altmannshofer, T. Asaka, B. Batell and F. Bezrukov et al., [SHiP Collaboration], arXiv:1504. 04855 [hep-ph].

[5] M. Anelli, S. Aoki, G. Arduini, J.J. Back and A. Bagulya et al., [SHiP Collaboration], arXiv:1504. 04956 [Physics.ins-det]. 
[6] R. Foot and X. G. He, Phys. Lett. B 267, 509 (1991).

[7] G. W. Bennett et al., [Muon g-2 Collaboration], Phys. Rev. D 73, 072003 (2006).

[8] P. Jean, J. Knödlseder, V. Lonjou, M. Allain and J.-P. Roques et al., Astron. Astrophys. 407, L55 (2003).

[9] R. A. Flores and J. R. Primack, Astrophys. J. 427, L1 (1994).

[10] B. Moore, Nature 370, 629 (1994).

[11] A. A. Klypin, S.Gottlober, A. V. Kravtsov and A. M. Khokhlov, Astrophys. J. 516, 530 (1999).

[12] B. Moore, S. Ghigna, F. Governato, G. Lake and T. Quinn et al., Astrophys. J. 524, L19 (1999).

[13] B. Batell, M. Pospelov and A. Ritz, Phys. Rev. D 80, 095024 (2009).

[14] B. Patt and F. Wilczek, arXiv:hep-ph/0605188.

[15] Y. G. Kim, K. Y. Lee, C. B. Park and S. Shin, Phys. Rev. D 93, 075023 (2016).

[16] Y. G. Kim, K. Y. Lee and S. Shin, J. High Energy Phys. 0805, 100 (2008).

[17] Y. G. Kim and S. Shin, J. High Energy Phys. 0905, 036 (2009).

[18] D. S. Akerib et al., LUX Collaboration, Phys. Rev. Lett. 116, 161301 (2016).

[19] D. S. Akerib et al., LUX Collaboration, Phys. Rev. Lett. 116, 161302 (2016).

[20] P. Minkowski, Phys. Lett. B 67, 421 (1977).

[21] T. Yanagida, Conf. Proc. C 7902131, 95 (1979).

[22] M. Gell-Mann, P. Ramond and R. Slansky, Conf. Proc. C 790927, 315 (1979).

[23] S. Glashow, In Quarks and Leptons, Cargese Lectures, Plenum (NY, 1980), p. 687.

[24] T. Asaka, S. Blanchet and M. Shaposhnikov, Phys. Lett. B 631, 151 (2005).

[25] T. Asaka and M. Shaposhnikov, Phys. Lett. B 620, 17 (2005).

[26] M. Shaposhnikov, Nucl. Phys. B 763, 49 (2007).

[27] M. Shaposhnikov, J. High Energy Phys. 0808, 008 (2008).
[28] K. Babu and R. Mohapatra, Phys. Rev. Lett. 70, 2845 (1993).

[29] B. Bajc, G. Senjanovic and F. Vissani, Phys. Rev. Lett. 90, 051802 (2003).

[30] K. Babu and C. Macesanu, Phys. Rev. D 72, 115003 (2005).

[31] G. Altarelli and D. Meloni, J. High Energy Phys. 1308, 021 (2013).

[32] A. Ibarra, E. Molinaro and S. Petcov, Phys. Rev. D 84, 013005 (2011).

[33] T. Asaka, M. Laine and M, Shaposhnikov, J. High Energy Phys. 0701, 091 (2007), Erratum: J. High Energy Phys. 1502, 028 (2015).

[34] See http://www.nu.to.infn.it/exp/all/cern-ps-191/ (accessed Aug. 24, 2016).

[35] K. Kodama, N. Ushida, C. Andreopoulos, N. Saoulidou and G. Tzanakos et al., [DONuT Collaboration], Phys. Lett. B 504, 218 (2001).

[36] K. Kodama et al., [DONuT Collaboration], Phys. Rev. D 78, 052002 (2008).

[37] N. Agafonova et al., [OPERA Collaboration], Phys. Rev. Lett. 115, 121802 (2015).

[38] K. Kodama, N. Saoulidou, G. Tzanakos, B. Baller and B. Lundberg et al., Nucl. Instrum. Meth. A 493, 45 (2002).

[39] K. Niu, E. Mikumo and Y. Maeda, Prog. Theor. Phys. 46, 1644 (1971).

[40] J. A. Northrop and J. C. Gursky, Nucl. Instrum. 3, 207 (1958).

[41] S. Kubota, M. Hishida, M. Suzuki and J.-z. Ruan(Gen), Phys. Rev. B 20, 3486 (1979).

[42] S. Kubota, M. Suzuki and J.-z. Ruan(Gen), Phys. Rev. B 21, 2632 (1980).

[43] M. J. Carvalho and G. Klein, J. Lumin. 18/19, 487 (1979).

[44] J. K. Woo, J. W. Ko, S. Na, Y. J. Kim and H. S. Lee, J. Korean Phys. Soc. 62, 839 (2013). 